\title{
Philosophy of Modeling in the 1870s: A Tribute to Hans Vaihinger
}

\author{
Karlis Podnieks \\ Faculty of Computing, University of Latvia \\ 19 Raina Blvd., Riga, LV-1586, Latvia \\ karlis.podnieks@lu.lv
}

\begin{abstract}
This paper contains a detailed exposition and analysis of The Philosophy of "As If" proposed by Hans Vaihinger in his book published in 1911. However, the principal chapters of the book (Part I) reproduce Vaihinger's Habilitationsschrift, which was written during the autumn and winter of 1876. Part I is extended by Part II based on texts written during 1877-1878, when Vaihinger began preparing the book. The project was interrupted, resuming only in the 1900s. My conclusion is based exclusively on the texts written in 1876-1878: Vaihinger was, decades ahead of the time, a philosopher of modeling in the modern sense - a brilliant achievement for the 1870s! And, in the demystification of such principal aspects of cognition as truth, understanding and causality, is he not still ahead of many of us? According to Vaihinger, what we set beyond sensations is our invention (fiction), the correspondence of which with reality cannot (and need not) be verified in the mystical, absolute sense many people expect.
\end{abstract}

Keywords: fictionalism, fiction, hypothesis, dogma, sensations, reality, truth, understanding, modeling

\section{Introduction}

“Aller Dogmatismus ist hier verschwunden, " according to Simon et al. (2013). I suspect that by saying this regarding his book, Hans Vaihinger meant, in fact, that if people would adopt his Philosophie des Als $\mathrm{Ob}$, most of traditional philosophy would become obsolete.

Is this why the attitude of many philosophers to Vaihinger's "fictionalism" has been and remains one of neglect? For more details, see Fine (1993) and Simon (2014). However, at the very end, Fine concludes that this attitude is mistaken:

"Preeminently, the industry devoted to modeling natural phenomena, in every area of science, involves fictions in Vaihinger's sense. If you want to see what treating something "as if" it were something else amounts to, just look at most of what any scientist does in any hour of any working day.“ (p. 16) 
"... the dominant self-conception of postwar science has been that of sciences as the builder of useful models. Vaihinger was surely the earliest and most enthusiastic proponent of this conception, the preeminent twentieth-century philosopher of modeling." (p. 18)

For a similar conclusion, see Suárez (2009):

"Vaihinger's work is unfortunately not sufficiently well known today, but he should appear to philosophers of science as an extremely contemporary figure."

However, it seems to me that Vaihinger deserves more - recognition as one of history's greatest philosophers.

I have read the entire book: Hans Vaihinger, Die Philosophie des Als Ob, System der theoretischen, praktischen und religiösen Fiktionen der Menschheit auf Grund eines idealistischen Positivismus, 7. und 8. Auflage, Verlag von Felix Meiner, Leipzig, 1922, 804 p. A searchable copy from Internet Archive (archive.org) was also extremely helpful.

My final conclusion, elaborated below, is that Vaihinger was, indeed, decades ahead of the time, a philosopher of modeling in the modern sense - a brilliant achievement for the 1870s! And, in the demystification of such principal aspects of cognition as truth, understanding and causality, is he not still ahead of many of us? According to Vaihinger, what we set beyond the world of sensations is our invention (fiction), the correspondence of which with reality cannot (and need not) be verified in the mystical, absolute sense most people expect.

I agree with Friedrich Albert Lange who predicted in 1875:

"Ich bin sogar überzeugt, dass der von Ihnen hervorgehobene Punkt einmal ein Eckstein der philosophischen Erkenntnistheorie werden wird.“ F. A. Lange, May 16, 1875, in a letter to Vaihinger. (Quoted after Vaihinger's Vorbemerkungen zur Einführung, p. XIII, left out of the English translation.)

"I am even sure that the point stressed by you once will become a cornerstone of the philosophical theory of cognition.“ (Translations of text fragments left out of Ogden's English translation are all my own work.)

The first edition of the book was published in 1911. However, the principal chapters (the General Introduction and Part I - "Basic Principles") reproduce parts of Vaihinger's Habilitationsschrift written during the autumn and winter of 1876 (when he was 24 years old). Part I is extended by Part II - "Amplified Study of Special Problems" based on texts written during 1877-1878, when Vaihinger began preparing the book. The project was interrupted for more than 25 years, resuming only in the 1900 s. Part III - "Historical Confirmations" was written after the resumption. See Vaihinger's reminiscences (1921) and the chronology of Vaihinger's life by Simon et al. (2013).

In "Vorbemerkungen zur Einführung" (written after the resumption and left out of the English translation) Vaihinger calls on the congenial work of Mach, Peirce and Nietzsche, as well as on the growing popularity of philosophical voluntarism and pragmatism as his main inspirations to let 
“... mein im Pulte liegendes Werk, dem die Rolle eines Opus Postumum zugedacht war, doch noch bei Lebzeiten erscheinen zu lassen.“ (p. XIV-XV)

“... the work lying in my desk, and intended initially for the role of an Opus Postumum, to be published still during my lifetime.“”

Poincaré's "La Science et l'Hypothèse" (1902) is also mentioned in this context. Einstein wrote in a letter to Vaihinger (May 3, 1919) that he found in Vaihinger's book "a manner of looking at things that is very close to my own" and that "Poincaré too is closely related to you“ (Einstein, 1919, Sass, 1979).

I tried to build a model as compact, authentic and complete as possible of Vaihinger's philosophy of 1876, trying to avoid re-formulations and qualifications in modern terms. This is why I use quotations so extensively: I am trying to demonstrate the authenticity of the exposition. To expose the situation of 1870s correctly, in the model, I do not refer even to Vaihinger's own later formulations that appear in the prefaces and Part III of the book, and in his reminiscences (1921). To keep the paper reasonably short (sic!), I did not attempt (mainly) to trace ideas back to their origins. At the end, I verified and corrected my compact model by reading most of the book another time(s). (By the way, reading the German original, even for the third time brings with it an appreciation of reading good literature, and reveals new insights! Einstein: "I find your book very enjoyable and intend to absorb it bit by bit.")

(However, some time later Einstein became more skeptical about Vaihinger's "Als-Oberei". For the historical context, see Hentschel (2014). For me, Einstein's irony seems to be an early symptom of his philosophical in-consequence that will lead in the future to his dropping out of mainstream physics.)

I used the English translation of Vaihinger (1924) by Charles Kay Ogden as the source of English terminology and quotations (referred to as ET throughout the paper). The translation includes Vaihinger's reminiscences (1921), but the main text of the book is reduced considerably: the General Introduction and Part I are 327 pages in German compared to 177 pages in English; Part II is reduced from 285 to 92 pages, Part III from 178 to 92 pages. (Pages in the German original are about 1/10 shorter than pages in the translation.)

Throughout the book, all the traditional pre-1876 celebrities in the history of philosophy are mentioned (as sources of ideas) many times:

Parmenides, born around 515 BCE, is mentioned about 24 times (in the General Introduction and Parts I and II), Plato, 428 BCE, is mentioned 48 times; Aristotle 384 BCE (49), Galileo, born 1564 (16), Hobbes 1588 (10), Descartes 1596 (43), Spinoza 1632 (30), Locke 1632 (26), Newton 1643 (76), Leibniz 1646 (204), Berkeley 1685 (27), Hume 1711 (40), Condillac 1714 (43), Adam Smith 1723 (41), Bentham 1748 (15), Goethe 1749 (24), Fichte 1762 (17), Hegel 1770 (25), Schopenhauer 1788 (16), Mill 1806 (31), Darwin 1809 (16), Taine 1828 (15), with a special attention to Kant 1724 (334).

However, Vaihinger claims to have received much influential support from German philosophers who are today not considered "first class":

Johann Friedrich Herbart (mentioned about 107 times), Friedrich Albert Lange (87), Hermann Lotze (87), Ernst Laas (79), Heymann Steinthal (72), Christoph von Sigwart 
(48), Gustav Fechner (42), Eugen Dühring (35), Salomon Maimon (28), Richard Avenarius (25), Otto Friedrich Gruppe (20), Moritz Wilhelm Drobisch (16), Karl Theodor Ferdinand Grün (15), Karl Robert Eduard von Hartmann (15), Carl Neumann (15), and so on (listed in decreasing order of number of mentions in the General Introduction and Parts I and II).

Note. Throughout the paper, if not specified otherwise, all occurrence counts refer to the General Introduction and Parts I and II of the German original, i.e., the texts written in $1876-1878$.

A full description of my compact "Model-Vaihinger-1876", based exclusively on the General Introduction and Parts I and II of the book, follows in Section 2.

My intention is to present Vaihinger's Philosophie des Als $\mathrm{Ob}$ as it was formulated by the author in 1876-1878. I did not find in the book any justification for the doubts expressed, for example, by Mühlpfordt et al. (2001), that the text of Part II as published in 1911 is based on "einem moderneren Erkenntnis- und Entwicklungsstand" when compared with the text of the 1870 s version (p. 215). In fact, the General Introduction and Parts I and II do not refer to the work published in 1879 or later, with only two exceptions that were added later - in the footnotes:

On page 62 - the November 6, 1876 address by Gustav Rümelin, attended by Vaihinger personally, but published only in 1881 ;

On page 282 - the book by Friedrich Kuntze on Maimon's philosophy published in 1912 was not used by Vaihinger, but the reference was added for the reader's convenience.

Throughout the entire book, including text written in the 1900s, Vaihinger does not mention such terms as Elektron, Uran, Strahlung, and neither names, nor the work of Röntgen, Becquerel, Curie, Thomson, Lorentz, Planck and Einstein.

Thus, the entire book is, indeed, based only on the scientific and philosophical material available to Vaihinger in 1878.

In "Vorbemerkungen zur Einführung" (written in the 1900s, and left out of ET) Vaihinger refers to the (now well-known) work of Peirce from 1878, which was not available to him at the time:

"Dies war wohl auch der Grundgedanke, der dem eigentlichen Vater des Pragmatismus, C. S. Peirce, im Jahre 1878 vorschwebte, als er die ersten Grundlinien dieser Richtung kurz skizzierte, also wieder genau um dieselbe Zeit, als das vorliegende Werk entstand, ...“(p. XV)

"This was also the basic idea that occurred in 1878 to the true father of pragmatism, C. S. Peirce, when he drafted the first guidelines of this school of thought [pragmatism], thus, again, at the same time when the present work [Parts I and II of Vaihinger's book] was developed.“

But let us start with an

\section{Ultra-compact model}

Probably, the best concise exposition of The Philosophy of "As If" can be found in Chapter XXIX of Part I where Vaihinger explains why the ancient Greeks did not arrive at the idea of fiction: 
"The form of the conscious fiction only developed after people had learnt by experience, long enough and often enough, that thought does not mirror reality and yet does arrive at reality, that mental processes [die Denkrechnung] are ultimately adequate. It was then that the idea arose that the phenomenal world [die Welt der Erscheinung] was not a mere illusion, but a symbolic and expedient [zweckmässig formiertes] conceptual construct [Vorstellungsgebilde] enabling us to move and to orientate ourselves in the world of the unknowable and the unrealizable, without knowing it as it is. We do this by forming in its place a conceptual construct which has become more appropriate and suitable through a progressively richer experience, and which we can substitute for the unexplained world, at any rate practically; though theoretically this conceptual world with its contradictions cannot be a mere reflection of reality but only a subjective instrument." (p. 140e, 239, my emphases added)

A later, sharpened formulation from Vaihinger's reminiscences (1921):

'I called this work, The Philosophy of 'As if' because it seemed to me to express more convincingly than any other possible title what I wanted to say, namely that 'As if', i.e., appearance, the consciously-false, plays an enormous part in science, in worldphilosophies and in life. I wanted to give a complete enumeration of all the methods in which we operate intentionally with consciously false ideas, or rather judgments. I wanted to reveal the secret life of these extraordinary methods.“ (p. XLIe of ET).

Thus, Vaihinger's ambition was to propose not merely a new understanding of human cognition as based on deliberate fictions. He was proposing more: "A System of the Theoretical, Practical and Religious Fictions of Mankind," a new understanding of cognition, ethics and religion as based on deliberate fictions (p. 49-50e, 69), a new "fully satisfactory view of world and life" (p. XX in the German original, written in the 1900s, left out of ET).

"... the importance of our theory for practical philosophy is obvious. All the nobler aspects of our life are based upon fictions. We have already contended that a pure ethic can only be established by the recognition of its fictional basis. ... It is an error to suppose that an absolute truth, an absolute criterion of knowledge and behaviour, can be discovered. The higher aspects of life are based upon noble delusions [edelen Täuschungen]. Thus our theory clearly leads to a practical view of the world very different from the ordinary one.“ (p. 84e, 142-143)

"Anyone who finds such knowledge [about morality and religion as based on deliberate fictions] terrible, who regards it as a harmful truth and therefore feels constrained to cast aside his ideals as valueless - such a man has never really believed in his ideals with all his heart [mit aller Macht seiner Seele].” (p. 49e, 68)

Note. For more about Vaihinger's approach to practicing religion in a fictional framework, see Koridze (2014). See also Steffe (2015) for interviews with religious radical constructivists. 


\section{Model-Vaihinger-1876}

According to Vaihinger's idealistic positivism (the title of the book), the overall architecture of human cognition is as follows.

The starting point is a positivist one.

\section{Sensations are the starting point and the terminus of thinking.}

We have no direct access to objective reality; we can access directly only our local world of sensations (Empfindungen). This local world seems to function independently of us, but we can take practical actions to affect it and see how this results in the sensations again.

“... we do not know objective reality [das objektive Sein] absolutely but only infer [erschliessen] it (and this is also an ordinary scientific view) [in 1876?]... It is not the correspondence with an assumed "objective reality" that can never be directly accessible to us,... which, in our view, guarantees that thought has fulfilled its purpose; it is rather the practical test as to whether it is possible with the help of those logical products [i.e., products of thinking] to calculate events that occur without our intervention and to realize our impulses appropriately..." (p. 3e, 4-5)

“... sensations are the starting-point of all logical activity [i.e., thinking] and at the same time the terminus to which they run,..." (p. 6e, 8)

Vaihinger declares his complete rejection of "truth" in "the usual sense of the term" (i.e., as correspondence with an assumed "objective reality"):

“... such a general agreement would still offer no guarantee of the "truth" of combinations of ideas [Vorstellungsverknüpfungen]. Only the practical test is the final guarantee; but even here we can only conclude that combinations of ideas fulfil their purpose, and have been rightly formed. From the standpoint of modern epistemology [in 1876!] we can therefore no longer talk about "truth" at all, in the usual sense of the term." (p. 4e, 5)

However, as we will see below, Vaihinger in fact retains a significant part of the correspondence approach to knowledge: according to him, we are able to acquire "certain knowledge" (sicheres Wissen) about the world of sensations that is directly accessible to us.

Note that (here and throughout the book) Vaihinger uses the term "logical" in the sense of "related to human thinking": logical products (products of thinking), logical activity, logical processes (logischen oder Denk-Prozesse, p. 2, i.e., thinking), logical function (logische Funktion oder anders ausgedrückt, ... die theoretische Tätigkeit, p. 6), logical optimism and pessimism (dogmatism and skepticism, see below). Of course, for modern readers, the term "logical" carries with it "formal logic" as an undesired connotation.

Thinking is an instrument in the service of life, a part of the cosmic process.

The fundamental purpose of human thinking is calculation (Berechnen) of actions that affect the world of sensations in desired ways: 
"Thought ... must be regarded as a mechanism, as a machine, as an instrument in the service of life;... the purpose of thought must be sought not in the reflection of a so-called objective world, but in rendering possible the calculation of events and of operations upon them.“ (p. 5e, 7)

Human thinking emerged at a certain stage of "organic development" and is itself "a part of the cosmic process" (ein Teil des kosmischen Geschehens):

"Subjective processes of thought inhere in the entire structure [Gefüge] of cosmic phenomena. They represent the highest and ultimate results of organic development, and the world of ideas [Vorstellungswelt] is the fine flower of the whole cosmic process; but for that very reason it is not a copy of it in the ordinary sense. Logical processes [i.e., human thinking] are a part of the cosmic process and have as their more immediate object the preservation and enrichment of the life of organisms; ..." (p. 15-16e, 22)

Thinking takes place within the brain.

More precisely, thinking takes place "within that part of reality which we regard as the brain" because even our idea of a nervous system is "a construct of our productive phantasy":

"When we say that our conceptual world [Vorstellungswelt] lies between the sensory and motor nerves we are making use of fictional language for, in actual fact, we only have sensations. Our ideas both of movement and nerves, that is to say, of matter, are constructs of our productive phantasy, of fiction. The whole conceptual world is, in other words, inserted between sensations, these alone are ultimately given. Only certain sequences of sensation are given to us. The conceptual world is thus a structure [Gebilde] made up of elementary sensations and their residue [Resten], ... By reason of the condensation, interconnection, etc. of sensations, which takes place within the brain, i.e., within that part of reality which we regard as the brain, a more advanced and more developed structure is created for the enrichment and perfection of human activity." ( $p$. 66-67e, 96)

Hence,

"The psyche... works according to psycho-mechanical and psycho-chemical laws..." (p. 101e, 177)

And thus,

"The comparison of thought with calculation is far more correct and legitimate than was formerly supposed. It is a detailed knowledge of the remarkable methods of mathematics which first enables us to realize that thought employs the same methods." (p. 153e, 271-272)

\section{Products of thinking cannot be copies of reality.}

Due to the specific substrate of thinking ("that part of reality which we regard as the brain"), processes and products of thinking are completely different from the things and processes to which they seem to relate. 
"However we may conceive the relation of thought and reality, it may be asserted from the empirical point of view, that the ways of thought are different from those of reality [des Seins], the subjective processes of thought concerned with any given external event or process have very rarely a demonstrable similarity to it.“"(p. 7-8e, 10).

Even elementary sensations are not copies of reality:

"Not even elementary sensations are copies of reality [Abbilder der Wirklichkeit]; they are rather mere gauges [Massstäbe] for measuring the changes in reality.“ (p. 16e, 23)

Products of thinking are not pictures of events, but are events themselves:

"All these concepts are not pictures of events, but are themselves events, a part of the cosmic process. They occur of necessity at a certain stage of organic development; the cosmic process is continued in these ideas. They are indeed psychical products, psychical processes, and psychical events are certainly a part of the cosmic process. The world as we conceive it is only a secondary or tertiary construction, arising in our heads through the play of the cosmic process... This conceptual world is not a picture of the actual world but an instrument for grasping and subjectively understanding that world.“ (p. 63e, 88)

"It is improbable and unnatural that two processes on such different bases, those of subjective thought [Vorstellen] and objective events, should take the same form." (p. $158 \mathrm{e}, 288)$

Rejecting Hegel's approach, Vaihinger introduces on page 8e, 10 the term "general error of philosophy" (Generalirrtum der Philosophie) to denote "the confusion of thoughtprocesses with [objective world-]events."

"Whatever the objective reality may be, one thing can be stated with certainty - it does not consist of logical functions, as Hegel once thought." (p. 8e, 10).

"Actually the greatest and most important human errors originate through thoughtprocesses being taken for copies of reality itself..." (p. 8e, 11-12) [a somewhat modernized translation of: ... dass man die Wege des Denkens für die Abbilder der realen Verhältnisse selbst nimmt...]

At this point ends the positivist part of Vaihinger's philosophy and begins the idealist part.

\section{To attain its purpose, thinking must create artificial means.}

The following sentence was left out of ET:

“... die organische, zwecktätige Eigenschaft des Denkens sich gerade darin zeigt, künstliche Mittel zu schaffen, um seinen Zweck zu erreichen." (p. 8, emphasis of the original)

“... the organic, purposive feature of thinking manifests itself exactly in creating of artificial means in order to attain its purpose."

Vaihinger uses the term "artificial" as the opposite of "natural": 


\begin{abstract}
"Thought is bent on continually perfecting itself and thus becomes a more and more serviceable tool. For this purpose it expands its province by inventing instruments, like other natural activities. The arm and the hand do the same, and most ordinary instruments are to be regarded as elongations and extensions of these organs. The natural function of thought, which we spoke of above as a tool, also expands its instrumentality by the invention of tools, means of thought, instruments of thought, one of which [namely, fictions] is to form the subject of our enquiry.“ (p. 6e, 8)
\end{abstract}

Thus, "the province of thinking" includes both natural and artificial means and products. The dividing line between "natural" and "artificial" Vaihinger defines as follows:

"The normal and most natural methods of thought always have as their primary object the formation of those particular apperceptions that are of a final and definitive character; and only such ideational constructs [Vorstellungsgebilde] are formed as can be shown to correspond to some kind of reality [welchen eine entsprechende Wirklichkeit nachgewiesen werden kann]. It is in fact the essential object [das eigentliche Ziel] of science to develop only such ideas as have an objective correlate and to eliminate all admixture of the subjective." (p. 15e, 21)

Thus, what is natural "corresponds to some kind of reality," where "reality" means the world of sensations. Here, Vaihinger demonstrates for the first time that, when it comes to sensations, he is ready to accept the correspondence approach to knowledge.

Note. The term Vorstellungsgebilde occurs in Parts I and II about 95 times. Ogden translates it somewhat unusually as "ideational constructs". A more literal translation would be "imagined constructs".

\title{
Technical rules of thought (logic)
}

As the first instrument that extends "the province of thought," Vaihinger considers logic to be "technical rules of thought" that were developed for direct handling of "the most frequent, regular and important" situations:

"Every natural faculty, and this applies to all organic functions, can, through practice, development and hereditary transmission, be raised to an art [Kunst]. Only in this sense can thought be an art.“ (p. 8e, 12)

"Certain technical rules [Kunstregeln] are developed: the totality of these rules is called the technology [Kunstlehre]; and such is logic, whose chief task is to present and establish the technical rules of thought." (p. 9e, 14).

"Methodology, ..., had endeavoured to collect the technical rules of thought in their completeness and to employ [verarbeiten] them systematically. It has succeeded in registering, analysing and systematically establishing those technical operations and manipulations which are the most frequent, regular and important.“ (p. 10e, 15).

Throughout the book, rules of induction are used as the main example of "technical rules of thought" ("the regular methods of ordinary induction," p. 11e, 16).

Are these "technical rules of thought" considered natural or artificial? Vaihinger does not address this question directly. However, when explaining on pages 21-22 (left 
out of ET) how induction works, he considers it to be a "natural" method: if successful, induction leads to certain knowledge about the world of sensations.

\section{Artifices (fictions)}

"Technical rules of thought" were developed for direct handling of the most frequent and regular situations. However, these regular means (induction) run into difficulties when less regular and more complicated situations occur:

"Just at the points where the empirical method of natural science converges [zuspitzt] on the methods of exact mechanics and abstract [mathematischen] physics, and, where on the other hand they approach the complicated phenomena of social life, the insufficiency of purely inductive methods is clearly manifest. It is here that methods begin which present a higher synthesis of deduction and induction, where, that is to say, both these methods are united in the endeavour to solve difficulties which can only be overcome indirectly.

The methods to which we refer may be described as irregular in contrast to the regular methods of ordinary induction." (p. 11e, 16).

To handle such difficult situations, people are forced to give up logical purity (logische Reinheit und Unbeflecktheit) (p. 13e, 19) and are forced to invent artifices (Kunstgriffe):

"We make a distinction between rules [Kunstregeln] and artifices [Kunstgriffe] of thought. In other functions also this distinction is of value; the rules are the totality of all those technical operations in virtue of which an activity is able to attain its object directly, even when more or less complicated. In logic too we call such operations, and in particular those of induction, "rules of thinking" [Kunstregeln des Denkens]. The artifices, on the other hand, are those operations, of an almost mysterious character, which run counter to ordinary procedure in a more or less paradoxical way. ["In other functions"] They are methods which give an onlooker the impression of magic if he be not himself initiated or equally skilled in the mechanism, and are able indirectly to overcome the difficulties which the material in question opposes to the activity. Thought also has such artifices; they are strikingly purposive expressions of the organic function of thought.“ (p. 11e, 17)

At this point (p. 12e, 18) Vaihinger introduces the term "fiction":

"We are therefore dealing with a peculiar kind of logical product, a special manifestation of the logical function [human thinking]. We have already seen that this peculiar activity is expressed in what we call artifices, that its products are artificial concepts [Kunstbegriffe]. We would here, anticipating the outcome, substitute other terms for these expressions: our subject is the fictive activity of the logical function; the products of this activity - fictions.

The fictive activity of the mind [der Seele] is an expression of the fundamental psychical forces; fictions are mental structures [psychische Gebilde]. The psyche weaves this aid to thought out of itself; for the mind is inventive; under the compulsion of necessity, stimulated by the outer world, it discovers the store of contrivances [den Schatz an Hilfsmitteln] that lie hidden within itself." (p. 12e, 18-19)

Vaihinger's favorite examples of artifices-fictions (note that "psyche weaves this aid out of itself") throughout the book include categories (thing-attributes, whole-parts, causeeffect, general-particular), atoms, empty (physical) space and time, forces/energies, 
points/lines/surfaces of geometry, infinitesimals of the calculus (curved lines made up of infinitesimal straight segments, etc.), infinity, the botanical system of Linnaeus, Smith's egoism-based economic system, freedom, ethical ideals, legal and religious concepts, and Kant's Ding an sich. Thus, here belong not only the "calculating artifices" (my term) of physics and mathematics, but also "all higher morality" (p. 50e, 69, details below).

Our fictional activities (fiktive Tätigkeit) began thousands of years ago:

"Mythology, in so far as it may be regarded as the common mother of religion, poetry, art and science, shows us the first expression in free constructive [freigestaltende] activity of the inventive faculty [der Einbildungskraft], of imagination and of phantasy. It is here that we first find products of phantasy which do not correspond to reality [denen kein Wirkliches entspricht].“(

Note. Thus, religion, poetry, art and science are on a par? More about this thesis below.

\section{The term "fiction"}

Vaihinger proposes calling artifices fictions (p. 12e, 18).

In Chapter XXIII - "Collection of Expressions for Fiction" he presents a list of possible synonyms of this term: Kunstgriffe (artifices), Kniffe (tricks, devices), Erdichtungen (inventions), Phantasien, Imagination, Surrogate, Substitutionen, Suppositionen, Gerüste (scaffoldings), and many others coming from various authors. In the end (left out of ET), Vaihinger concludes that the best German term for an artifice would be Finte (feint):

"Offenbar ist Finte das beste deutsche Wort für Fiktion und bezeichnet das Erfinderische, Schlaue, welches in der logischen Funktion sich zeigt, welche wir oben als eine organische und darum zwecktätige Funktion beschrieben haben.“ (p. 171, left out of ET)

"Obviously, Finte is the best German word for fiction, it denotes the inventive and smart that manifests in the logical function [in human thinking], and that we have described above as an organic and therefore a purposive function."

He nevertheless chooses to use the term Fiktion:

"This approximately complete collection of names used for fiction shows how important they have always been, and how a really central term has hitherto been lacking. This we shall now try to supply by the introduction of the term, fiction." (p. 97e, 171)

Probably, by choosing Finte as his base term instead of Fiktion (which is "contaminated" with derogatory connotations) he could have avoided at least part of the resistance to his philosophy, the very invention of the term "fictionalism" included. However, later on in the 1920s, Vaihinger himself seems to have been not saddened at all by this term (see Preface to ET, p. VIIIe). In the book, this term appears only once, in Part III, written in the 1900s - as a reference to Kant's "radikale Fiktionalismus" (p. 750, left out of ET). 
The action of creating a fiction Vaihinger denotes mainly by using the verb fingieren (the root "fingier-" occurs about 110 times), or erfinden ("invent", the root "erfind-" occurs about 30 times). Ogden translates fingieren mainly as "to imagine" (the corresponding English text contains the root "imagin-" about 145 times, and the root "invent-" about 35 times).

\section{The distinguishing feature of fictions}

The following general characteristic of fictions occurs in the book several times, but the first occurrence on page 24 of the German original was left out of ET:

"Als allgemeinen Typus der Fiktion haben wir oben die Formierung solcher Vorstellungsgebilde erkannt, welche in der Wirklichkeit keinen Vertreter finden.“ (p. 24)

"As a general type of fictions we have recognized above the formation of ideational constructs for which, in the reality [i.e., in the world of sensations] no exponent can be found.“

In other words, to overcome the difficulties,

"Thought begins with slight initial deviations from reality (half-fictions), and, becoming bolder and bolder, ends by operating with constructs [Vorstellungsgebilden] that are not only opposed to the facts [welche nicht mehr bloss dem Gegebenen widersprechen] but are self-contradictory.“(

Thus, Vaihinger here (on p. 16e, 24) introduces for the first time the idea of contradictions as the distinguishing feature of many fictional constructs. He introduces here also the principal (for him) distinction between semi-fictions and real fictions:

\footnotetext{
"Ideational constructs are in the strict sense of the term real fictions when they are not only in contradiction with reality but self-contradictory in themselves; the concept of the atom, for example, or the Ding an sich. To be distinguished from these are constructs which only contradict reality as given, or deviate from it, but are not in themselves selfcontradictory (e.g. artificial classes). The latter might be called half-fictions or semifictions." (p. 16e, 24)
}

\section{Semi-fictions}

As examples of semi-fictions Vaihinger considers the botanical system of Linnaeus, other systems of artificial classification, and Smith's egoism-based economic system ( $\mathrm{p}$. 18e, 26, p. 98e, 172). According to Vaihinger, these systems deviate from reality, but are not self-contradictory.

In Chapter I - "Artificial Classification“" and Chapter II - "Abstractive (Neglective) Fictions," Vaihinger considers the simplest methods of creating semi-fictions.

Surprisingly, an entire 18 pages of the German original are devoted to the topic of artificial classifications (Ch. I in Part I, $\S 1$ and $\S 2$ in Part II).

First of all, Vaihinger reviews the popular (at the time) problem of natural and artificial systems of classification: 
"All cosmic objects present special forms which are theoretically expressed in some classification, and when this specification [i.e., classification] corresponds with reality in every respect [in allen Gliedern] then it is a natural system. ...

A natural system is one in which entities are arranged according to the principles apparently followed by nature in their development. To put it briefly, the natural system of classification must be a copy [ein entspechendes Abbild] corresponding to the actual origins and the mutual relationship of all things.“ (p. 17e, 25)

On the contrary, artificial systems of classification (such as the botanical system of Linnaeus) are defined as simplified auxiliary groupings of objects. To distinguish between classes, in such systems a limited set of "characters" is selected (Linnaeus classified plants according to the numbers of stamens and pistils). Because of their simplicity, such systems can be practically useful and they can "render great services to science" by "enabling to gain a temporary general view":

"Artificial systems are thus [quoting d'Alembert] "one-sided systems, for since the grouping is made on the basis of special characters, it cannot be a true reflection of the richness of the whole." But such classifications, made on the basis of external, infrequent, secondary and accidental characters, afford a very practical aid to thought by enabling it to gain a temporary general view. In relation to the state of our knowledge, they are often all that is possible or practically useful.“ (p. 182e, 334)

"Yet in spite of their inaccuracy and partial erroneousness [Falschheit] they [artificial classifications] render great service to science." (p. 184e, 339)

In some fields, perfect ("natural") systems of classification may not be possible at all because "nature does not even suggest" them:

"In many fields we are thus forced to give up, either temporarily or finally, the hope of constructing a natural classification, and as Taine says in connection with his classification of the sensations, to remain content with a sort of revue, ... “ (p. 180e, 332)

"In these instances [in chemistry] we cannot help making an arbitrary classification or forming divisions that nature does not even suggest. There are no partitions in nature. It was Berzelius himself who, with reference to the earths, alkalies, metal-oxides, etc., called our attention to the fact that all our divisions are artificial and that no natural dividing line can be detected.“ (p. 183e, 338)

Speaking strictly, Vaihinger's qualification of artificial systems of classification as "deviating from reality," as "opposing the facts," and even as "erroneous" (falsch) is problematic. Indeed, in what sense could a precisely defined system of classification (such as the one proposed by Linnaeus) "deviate from reality"? Of course, a particular system may be better or worse at "rendering services to science," but how could it be "false"?

For example, how could it be "false" to classify animals according to their size? Because, it "falsely" puts tigers into the same class with calves and not with cats? (Vaihinger's own example on p. 330, left out of ET). In fact, any precisely defined system of classification cannot be "false". It represents a kind of tautology: "it classifies as it classifies", rendering more or less better services to science. 
Does this discrepancy mean that Vaihinger is implicitly applying here his definition of truth as "the most expedient error" (details below)? Namely, if we have proposed two competing systems of classification $\mathrm{A}$ and $\mathrm{B}$, and $\mathrm{B}$ renders better services to science than $\mathrm{A}$, does this mean that $\mathrm{A}$ is "false"?

Nevertheless, let us continue taking seriously Vaihinger's general definition of fictions as "constructs for which, in the reality no exponent can be found." But, contrary to Vaihinger's interpretation, by taking this definition literally, all precisely defined classifications should be qualified as non-fictional.

\section{Real fictions}

According to Vaihinger, real fictions (echte/eigentliche Fiktionen) are "not only in contradiction with reality but [are] self-contradictory in themselves" (p. 16e, 24).

The term echte Fiktion occurs 13 times, the term eigentliche Fiktion - 7 times.

Ogden translates the 20 occurrences of echte/eigentliche Fiktionen as "true fictions" (10 times) or "real fictions" (10 times as well). Suárez (2009) prefers a better term: "full or fully fledged fictions." Mathematicians would prefer "proper fictions".

Vaihinger's favorite examples of real fictions are: empty (physical) space and time, forces/energies, atoms, points/lines/surfaces of geometry, infinitesimals of the calculus (curved lines made up of infinitesimal straight segments, etc.), infinity, freedom, ethical ideals, legal and religious concepts, and Kant's Ding an sich.

\section{Atom as a real fiction}

Throughout the book, Vaihinger repeats many times his Lieblingsbeispiel of a real fiction: atom (the term is mentioned about 260 times). For Vaihinger (in 1876!), atoms are infinitely small (point-like) objects (p. 70e, 102), hence, they represent an internally contradictory concept. Indeed, how could point-like objects carry non-zero amounts of matter, and serve as centers of force? (p. 218-219e, 432-433)

"Unextended centres of energy [Kraftzentren] that are to be the basis of extension, are absolutely contradictory constructs. Something without extension, that nevertheless in its summation is to give us extension, is a contradiction. The idea of a reduction of matter to atoms is, then, a fiction." (p. 268e, 605)

Despite these internal contradictions, atom represents a necessary concept that enables calculations in chemistry and physics:

“... without the atom science falls. And yet, with it, true knowledge and understanding [wahres Wissen and Erkennen] are impossible. It is a group of contradictory concepts which are necessary in order to deal with reality [zur Berechnung der Wirklichkeit]. (p. 70-71e, 102)

Nevertheless, could the concept of atom "be dispensed with entirely"?

"Whether the concept [of atom] can be dispensed with entirely is an open question. To judge from the present state of the problem [in 1876], apparently it cannot; and to-day, at any rate, the atom is used by both the chemist and the physicist for the co-ordination [Anheftung, attachment?] of their laws, which they cannot yet formulate in a purely abstract manner.“ (p. 71e, 102) 
"The form of the atomic fiction is that matter must be treated as it would be, if there were atoms of which it was imagined to be composed. The form of the hypothesis connected with this assumption runs thus: only on the presupposition that atoms exist and only if they do exist, can the empirical appearance of material phenomena be explained." ( $\mathrm{p}$. $94 \mathrm{e}, 166$, emphases of German original retained)

Thus, it seems that Vaihinger would agree to accept the real existence of atoms, if atoms were proved to be the only possible structure allowing us to calculate "the empirical appearance of material phenomena“.

\section{Ethical ideals and legal notions as fictions}

In Chapter IX - "Practical Fictions," the concept of freedom is qualified as a real fiction:

"... one of the most important concepts ever formed by man, the idea of freedom; human actions are regarded as free, and therefore as "responsible" and contrasted with the "necessary" course of natural events. ... it not only contradicts observation [beobachtete Wirklichkeit] which shows that everything obeys unalterable laws, but is also self-contradictory,... In spite of all these contradictions, however, we not only make use of this concept in ordinary life in judging moral actions, but it is also the foundation of criminal law.“ (p. 43e, 59)

(The idea of nature "obeying unalterable laws" occurs in the General Introduction and Parts I and II 3 times and represents a concept of determinism as it existed in 1876.)

Ethical norms are necessary as regulative means, but they are based on unattainable and contradictory fictions - ideals:

“... just as science, and especially mathematics, leads to the imaginary, so life leads us to the impossible, which is quite justifiable - to absolute responsibility, absolute freedom and good actions for their own sake (absolute). Thou art a man and shouldst possess these noble sentiments - such is the command of the idealist and of society.

The imaginary (the absolute, ideal) is therefore justifiable in spite of its unreality. Without the imaginary factor neither science nor life in their highest form are possible." (p. $44 \mathrm{e}, 61)$

"Here belong all the so-called "ideals" of ordinary life. From a logical standpoint they are really fictions, but in practice they possess tremendous value in history. The ideal is an ideational construct contradictory in itself and in contradiction with reality, but it has an irresistible power [ungeheuren weltüberwindenden Wert]. The Ideal is a practical fiction.

... We include as fictions not merely indifferent theoretical operations but ideational constructs emanating from the noblest minds, to which the noblest part of mankind cling [an denen das Herz des edleren Teiles der Menschheit hängt] and of which they will not allow themselves to be deprived. Nor is it our object so to deprive them - for as practical fictions we leave them all intact; they perish only as theoretical truths. “ (p. 48-49e, 67-68)

According to Kant (in Vaihinger's terms), "true morality must always rest upon fictional basis." If our acting in accordance with morality is inspired not by ideals, but by a fear 
of real punishment, then this is "a matter of our lower interests, mere egoism," not morality (p. 49e, 68-69).

Thus, for Vaihinger, regulative ideals - as not only contradicting reality, but being self-contradictory as well - are real fictions.

\section{Religious concepts as fictions}

Vaihinger's attitude toward religion might be another major reason for his antipopularity (up to abandonment of his grave in Gertraudenfriedhof, Halle, Germany). In accordance with his general attitude toward human cognition, he qualifies religious concepts (God, prayer, immortality, reward, punishment, etc.) as real fictions (p. 48-49e, 66-68).

Vaihinger adopts the most radical ideas of Kant's philosophy of religion, articulated later by Kant's followers - Friedrich Karl Forberg and Friedrich Schleiermacher, but never fully maintained by Kant himself. However, in this respect, Vaihinger's Parts I and II, written in 1876-1878, seem less radical than Part III, written in the 1900s.

For "1876 state of the art" see, for example, Chapter IV - "Symbolic (Analogical) Fictions":

Quoting Fichte: "On the analogy of our mind we picture God as thinking, ... “ (p. 28e, 40)

"Thus, for instance, the relationship of God to the world, which for the philosopher Schleiermacher is completely unknowable, is conceived of by the theologian Schleiermacher on the analogy of the father-son relationship; ... "God" is not the "father" of men but he is to be treated and regarded as if he were. Such an interpretation is of tremendous importance for the practice of religion and worship, ... How close these analogical fictions are to myths I [Vaihinger] have already pointed out.“ (p. 28e, 41)

To justify his idea of religious concepts being real fictions, Vaihinger refers to the contradictions contained in them. For example, the necessity to pray contradicts the omniscience and omnipotence of God:

"Although Kant himself would not have agreed, Schleiermacher allows that prayer is a practical act, so long as there is still a consciousness of its being interpreted as if God would hearken to it. It is well-known, however, that this very concept of prayer contains antinomies which destroy [nicht zulassen] its objectivity. In prayer, at least in Islam and Christendom, there is an insoluble contradiction between the omnipotence of God, who can hearken to the prayer, and his omniscient government of the universe [Weltregierung], quite apart from [abgesehen noch von] the contradictions insolved [verwickelt, involved?] by the ordinary idea of prayer in relation to natural laws.“ (p. 47-48e, 65-66)

\section{Or, in Chapter XX:}

"With the current formula ["official fictions"], everyone who swears without believing in a God is indulging into a permissible fiction. The phrase "I swear by Almighty God," then means "I swear as if a God heard me." Such fictions are not merely permissible, but under certain circumstances are necessary, and resistance is ridiculous.“ (p. 84e, 142) 
And finally, in Part II, $\S 24$ :

"Christ taught: God is our father in heaven. He probably meant: You must regard God (whose existence for Christ was, of course, not a fiction, but a dogma), as if, just as though, he were your father and as if, just as though, he were present in the heavens [über den Wolken] as a constant external observer of your actions.“ (p. 264e, 602)

Thus, for Vaihinger, religious concepts - as self-contradictory - are real fictions.

In the General Introduction and Parts I and II Vaihinger applies Kant's term anthropomorph(istisch) 3 times, of them to religious concepts only once:

"Nor must we forget the theologians who in all ages - openly or tacitly - have distinguished between dogma and picture, between philosophical concept and conscious anthropomorphic expression.“ (p. 270e, 612)

In Part III, written in the 1900s, this term is applied more than 30 times.

Additionally, Vaihinger applies the term Personifikation/personifizieren 12 times, for example, "human tendency towards personification" (Personifikationstrieb des menschlichen Geschlechtes, p. 209e, 406). In Part III, this term is applied another 18 times.

\section{Kant's fiction of Ding an sich}

Vaihinger praises the fiction of Ding an sich as "der genialste Rechnungsansatz der Welt." Ogden translates this as "the most brilliant of all conceptual instruments" (p. 75e, 112). Elsewhere (p. 152e, 267), Ogden translates Rechnungsansatz as "methodological device" and as "schematic frame." A more literal translation would be: "the most brilliant initial assumption for calculation".

"Im Ding an sich hat die logische Funktion des diskursiven Denkens ihren Gipfel erreicht: das Ding an sich ist die letzte, aber auch notwendigste Fiktion: denn ohne diese Annahme ist uns die Vorstellungswelt “unbegreiflich“،“(p. 113, left out of ET)

"In Ding an sich, the logical function of discursive thinking culminates: the Ding an sich represents the ultimate, but also the most necessary fiction: while without this assumption the conceptual world is 'inconceivable' for us."

In other words:

"If we wish to speak of the real world at all, we must use some category, for otherwise it is not only unthinkable but even inexpressible.“ (p. 76e, 113)

In this way, "the whole world appears to be understood as an effect" (p. 75e, 112) and thus becomes calculable (berechenbar) for us:

“... dadurch wird nun die ganze Welt der Wirklichkeit berechenbar; ..." (p. 112)

Unfortunately, Ogden translates this as

"By this means the whole world of reality can be dealt with." (p. 76e)

thus leaving out "calculation".

Hence, the introduction of Ding an sich means, in fact, putting the fiction of independent reality beyond the world of sensations as its cause. And, of course, this is achieved by an "unjustified extension" - by applying a causal analogy: 
"If sensations are, in fact, essential reality [das eigentlich Reale], then their reduction, together with space, matter, etc., to the impact [einen Anstoss] of some unknown object, is an unjustified extension of the concept of cause and effect.“ (p. 75e, 112)

“.... indeed the whole method of the natural sciences, which [whose calculations] are founded on the assumption of an independent external world [welche eine unabhängige materielle Aussenwelt ihren Berechnungen zu Grunde legt], is only a one-sided abstraction.... The materialistic conception of the world is a necessary and useful fiction, but it is false as soon as it is taken for an hypothesis.“ (p. 199e, 379)

Of course, for Vaihinger, "the materialistic conception" is false because of its "numerous contradictions" (p. 76e, 113), which are caused by the above-mentioned "unjustified extension.“

Vaihinger's enthusiasm about ubiquitous contradictions in science and mathematics

As explained in Chapter X, according to Vaihinger, mathematical concepts are "contradictory fictions, mathematics being based upon an entirely imaginary foundation, indeed upon contradictions":

\footnotetext{
"Anyone acquainted with mathematics and its astonishing methods knows how the psyche proceeds in these cases... When the curve is subsumed under the straight line, it is thought of as made of an infinite number of straight lines.

The fundamental concepts of mathematics are space, or more precisely empty space, empty time, point, line, surface, or more precisely points without extension, lines without breadth, surfaces without depth, spaces without content [Erfüllung]. All these concepts are contradictory fictions, mathematics being based upon an entirely imaginary foundation, indeed upon contradictions.“ (p. 51e, 71)
}

Vaihinger refers here to the work of Dirichlet, Hankel, Kirchhoff, Gauss (calculation of the curvature of arbitrary surfaces by means of Hilfskugel) and Riemann (his concept of the curvature of three-dimensional space Vaihinger qualifies as "unlogisch" because of the "unjustified transference" from two dimensions to three). The idea of "spaces with $n$ dimensions" is, for Vaihinger, an unsuccessful attempt to avoid contradictions in the concept of three-dimensional space (p. 73-76, left out of ET).

For mathematicians, the reconstruction of calculus using the concept of limits was and remains today the final solution to all the controversies surrounding infinitesimals. Vaihinger was aware of the idea, but he rejected such a solution as hopeless:

"It is, therefore, an entirely vain procedure based upon a complete misunderstanding, if modern mathematicians imagine that they can rid the calculus of contradictions by going back to the concept of limits. Only weak spirits could be thus satisfied, and a strictly logical thinker must soon discover the same contradictions in the concept of 'limits'، (p. 253e, 554)

Vaihinger rejected the axiomatization attempts of mathematics ("postulates") as hopeless as well: 
"And it is this very contradictoriness that prevents us from contenting ourselves, without further ado [ohne Weiteres], with the favourite expression of the mathematicians that these and similar concepts are "postulates": for this last concept is vague and indefinite." (p. 228-229e, 473)

Thus, taken literally, Vaihinger's enthusiasm about the ubiquitous contradictions in science and mathematics might seem to discredit him as a serious thinker. Was he really not?

\section{Method of unjustified transference}

All the above-mentioned "contradictory" concepts were created by following a general method, called by Vaihinger "the method of unjustified transference" (die Methode der unberechtigten Übertragung), considered in Chapter XIV:

"The basic principle here also is an illegitimate application and transference of a logical method to cases that cannot properly be subsumed under it, or the treatment of such constructs [Gebilde] as numbers when they are not true numbers at all. Negative numbers are self-contradictory as all mathematicians admit; they are the extension of subtraction beyond the logical possibility of its application. Fractions are a product of the same method in division and so are irrational numbers in taking roots. The most preposterous of these number-constructs [das monströseste Zahlgebilde] are the imaginary numbers, and the constructions [their geometric representation, for example) given to them by Gauss, Drobisch, and others have in no way altered their fictional and contradictory nature.“( (p. 57e, 81)

Thus, for Vaihinger, "unjustified transference" inevitably creates contradictions.

From a $20^{\text {th }}$ century mathematician's point of view, when transferring some "old" concept to a new environment (thus, in fact, reasoning by analogy), we can indeed create contradictions, if we transfer the concept along with all of our "old" principles and intuitions surrounding it, without any changes. As a rule, in such situations, we must proceed more carefully, trying to transfer only the relevant principles and intuitions.

For example, let us imagine that we are proposing the idea of point-like atoms containing non-zero amounts of matter. If we will (with Vaihinger) transfer to this new situation the notion of density, then we will arrive at infinite densities, and this will indeed be a contradiction. The notion of density is not applicable to point-like atoms exactly because of the contradictions it creates. So, let us exclude the notion of density from "systems" (today we would say: theories and models) that operate with point-like objects. In this way, mathematicians, physicists etc. obtain new, useful and (at least relatively) consistent systems of concepts.

And exactly such was Einstein's reaction when reading Vaihinger's book in 1919: when a concept is considered "within the system to which it belongs", then it does not necessarily cause internal contradictions:

"If I find any fault with certain propositions posed by you with regard to the "fictions, " it is primarily that fictions are inherently contradictory. The concept "point," for ex. is, in my view, not inconsistent if one realizes that what is involved here is merely a concept, not an object of perception. I absolutely do not see how this concept, within its own system, leads to mutually contradictory conclusions.“"(Einstein, 1919; Sass, 1979). 
As an excuse for Vaihinger, let us note that looking at concepts strictly "within systems to which they belong" was not a common practice in the 1870 s. Non-Euclidean geometries and the beginnings of abstract algebra were not yet considered as serious achievements. Axiomatization of mathematics, Planck's quantum postulate, Einstein's relativity, Bohr's atom and other counter-intuitive concepts were yet to come.

This is why I would propose to rename the phenomenon of "unjustified transference" to "uncontrolled transference" - of principles, intuitions and other kinds of background knowledge. Let us call the kind of contradictions caused by uncontrolled transference UCT-contradictions. According to Vaihinger, contradictions of this specific kind are ubiquitous in science and mathematics. Are they, really?

In mathematics, UCT-contradictions indeed appear from time to time. For the first time they appeared around the $6^{\text {th }}$ century BCE with the discovery that the diagonal and sides of a square are in-commensurable (in modern terms, the discovery that $\sqrt{2}$ is an irrational number). For Vaihinger, the introduction of irrational numbers is an example of unjustified transference leading to UCT-contradictions (see the above quote from p. 57e, 81). Indeed, at some moment, the early Pythagoreans started to believe that any two line segments must possess a common measure. Thus, for them, the above discovery represented a real contradiction. But, in fact, it was only a UCT-contradiction and it was later removed by abandoning the belief in the general existence of common measures.

Note. In principle, Vaihinger could have extended his above passage about contradictions in mathematics by referring to Georg Cantor's theory of infinite sets invented just a few years before Vaihinger began writing his text. (Later, the two will become colleagues at the University of Halle.)

Cantor arrived at his set theory by transferring to infinite sets most (but not all) properties of finite sets. First of all, he did not transfer the principle "parts are smaller then the whole". When applied to infinite sets, this principle leads to contradictions - typical UCT-contradiction. For example, the set of even numbers represents "only a half" of all natural numbers, but one can label each number $n$ by the number $2 n$, and in this way, "a half" appears equally large as the "whole". Thus, the principle "parts are smaller then the whole" is not applicable to infinite sets, and must be left behind.

However, the most fundamental UCT-contradictions in Cantor's set theory were discovered in 1895 and subsequent years - the so-called antinomies of set theory. They were caused by uncontrolled transference to infinite sets of the so-called comprehension principle declared by Cantor like as follows: "for any property of things there is a set of all things possessing this property". By considering the property " $x$ is not a member of $x$ “, we arrive at Russell's paradox. The refined post-Cantorian set theories (such as ZFC) do not adopt the general comprehension principle. It is replaced by a carefully selected collection of those of its instances that are really necessary for building of mathematical structures (separation axioms, pairing axiom, union axiom, power-set axiom, etc.).

Internal contradictions do appear in scientific concepts as well, but they are by no means ubiquitous, appearing mainly during Kuhnian scientific revolutions. For example, Bohr's 1913 revolutionary model of the hydrogen atom represents a formally contradictory combination of classical physics (electrons "orbit" the nucleus, so they must constantly loose energy by emitting electromagnetic radiation) and a non-classical quantum principle (electrons have "stationary orbitals" where they do not need to emit 
radiation). Only some time later was this model (indeed full of UCT-contradictions) replaced by a model derived from a consistent quantum theory.

Now, when we are forced, with Einstein, to conclude that Vaihinger's insistence on "internal contradictions" as ubiquitous in science and mathematics, is a fault, what remains of his distinction between semi-fictions and real fictions?

Let us note that, according to Vaihinger, there is another significant line dividing human cognition.

\section{Going beyond sensations}

In Chapter IV - "Symbolic (Analogical) Fictions," Vaihinger arrives at the following general and radical thesis about the nature of cognition:

"Reality is, and must be thought of, on the analogy of human and subjective relations. All knowledge, if it goes beyond simple actual succession and co-existence [wenn sie nicht bloss tatsächliche Succession und Koexistenz feststellt], can only be analogical.

... All cognition is the apperception of one thing through another. In understanding, we are always dealing with analogy and we cannot imagine how otherwise existence [das Sein] can be understood.“ (p. 29e, 42)

"For it [Vaihinger's Critical Positivism), only the observed sequence and co-existence of phenomena exist, and upon these alone it takes its stand. Any explanation going beyond this [welche weitergeht] can only do so by using the accessories of discursive thought, i.e., through fictions." (p. 77e, 115)

"All these [fictions of substance, cause, whole, essence] are unjustified transferencefictions, since a relationship which only has a meaning within the sphere of experience is extended beyond this into the void [ins Leere].“ (p. 165-166e, 299)

Fictions are created in human minds, on "our side" of sensations:

"The psyche weaves this aid to thought out of itself; for the mind is inventive; under the compulsion of necessity, stimulated by the outer world, it discovers the store of contrivances [den Schatz an Hilfsmitteln] that lie hidden within itself.“ (p. 12e, 18-19)

According to Vaihinger, the world of sensations ("actual succession and co-existence") is accessible to us directly and is reliably knowable:

“... the establishment of an unalterable [unabänderliche] sequence and co-existence (or at any rate one that has never changed within our field of observation) is certain knowledge [sicheres Wissen].“ (p. 68e, 97)

For 1876, an emphasis on the fundamental role of analogies in cognition was plausible enough: even the top achievements of the time, such as the kinetic theory of gases, and Maxwell's electrodynamics were created by way of classical mechanical analogies. Invention of counter-intuitive (non-classical) structures began later with Planck's postulate, Einstein's relativity, Bohr's atom, etc.

However, before 1876, counter-intuitive structures were already invented in mathematics, beginning with the non-Euclidean hyperbolic geometry. Vaihinger does not refer to this work. He refers to Riemann's work (p. 73, left out of ET), but only to qualify as "unlogisch" the idea 
of the curvature of three-dimensional spaces. And to qualify $n$-dimensional spaces as "far more generalized structures... than are actually given [viel allgemeinere Gebilde ... als wirklich gegeben sind].“(

Thus, according to Vaihinger, we acquire two kinds of knowledge. The first is knowledge about "simple actual succession and co-existence," i.e., directly about the world of sensations. This knowledge is represented as certain knowledge, hypotheses and semi-fictions (more details below). The second kind is knowledge that goes beyond sensations. It is obtained by invention of structures that are put "into the void" (ins Leere), "to a non-existent and imaginary realm" (ins Nicht-Gegebene, p. 166e, 299-300), i.e., beyond sensations, as unobservables. The structures themselves are invented "on our side" of sensations, and when we put them beyond sensations we are reasoning by analogy. In this way, according to Vaihinger, we commit "unjustified transference", and thus fall into contradictions. However, as we already know, these are in fact UCT-contradictions which can be avoided. Let us generalize: contradictions can be avoided by transferring to the new situation not all, but only relevant principles, intuitions, etc., and, probably, by modifying them.

\section{Corrected model: observable versus unobservable fictions}

As we concluded above, Vaihinger's original (contradiction-based) dividing line, separating semi-fictions from real fictions cannot be seriously maintained. But in fact, the alternative dividing line introduced by Vaihinger is much more significant: this line separates fictions "on top" of sensations from fictions "beyond" sensations. In principle, we could try retaining Vaihinger's terminology by talking about semi-fictions as fictions "on top" of sensations and about real fictions as fictions "beyond" sensations. However, to avoid confusion, let us talk, instead, about observable and unobservable fictions. From the modern point of view, this seems not entirely perfect, but I think it fits well into Vaihinger's approach to cognition.

Thus, fictions of the first kind are invented as structures on top of sensations that serve us more or less perfectly, such as Vaihinger's favorite examples: Smith's egoismbased economic system and other abstractive fictions. Let us call this kind observable fictions.

Note that above we excluded from semi-fictions some other of Vaihinger's favorite examples: the botanical system of Linnaeus and other "artificial" systems of classification. As we concluded above, precisely defined systems of classification are nonfictional.

Fictions of the second kind are invented as structures intended to go beyond sensations, such as Vaihinger's favorite examples: Ding an sich, empty (physical) space and time, forces/energies, atoms, etc. Let us call this kind unobservable fictions.

Of course, at some points, this alternative dividing line differs from Vaihinger's original contradiction-based dividing line between semi-fictions and real fictions.

For example, the so-called categories (thing-attributes, whole-parts, cause-effect, general-particulars) can be applied to building both observable and unobservable fictions; so can infinity, points/lines/surfaces of geometry, infinitesimals of the calculus, and other mathematical concepts. For Vaihinger, these are all real fictions because of the internal contradictions they contain. 
But what about freedom, ethical ideals, and legal and religious concepts? From Vaihinger's contradiction-based point of view, all of these are real fictions because of the internal contradictions they contain. In the corrected model the situation is different. The fiction of freedom seems to be an unobservable fiction placed beyond the observable fictions: ethical ideals and legal concepts (some details below). This also applies to religious concepts: you can think of them as unobservable fictions beyond ethical ideals (some details below).

In practice, we all substitute our world of ideas for the actual world.

Frequently throughout the book (about 69 times), Vaihinger uses the term Vorstellungswelt. Ogden translates this about 19 times as "the world of ideas" consisting of "ideational constructs" (Vorstellungsgebilde), and about 19 times - as "conceptual world.“

"The true and final purpose of thought is action and the facilitation [Ermöglichung] of action. Looked at from this point of view the world of ideas is, taken as a whole, simply a means and its constituent elements are also merely a means. What we have here is a system of expedients of thought [Denkmitteln] which mutually help and support one another and whose final product is a scientifically purified conceptual world." (p. 66e, 95)

This world of ideas serves, indeed, as a well-adapted instrument. Hence,

"This naive and happy faith, this unquestioning confidence of the trustful, simple, natural man in the products of the logical function [human thinking]..." (p. 161e, 292-293).

"Man's natural tendency is to take his thought for the direct expression of reality, to see in the forms of thought forms of existence [Seinsformen]. Natural and naive thought takes all concepts and methods of the subjective conceptual world to be representative of an exactly corresponding reality." (p. 269e, 611)

However, the cognition-theorist (Erkenntnistheoretiker) must deliberately reject this naive approach:

"This construction [conceptual world] can be substituted for the actual world, and in practice we all do that; but it is not a picture of true reality, it is only a sign used in order to deal with reality, a logical expedient [Hilfsgebilde] devised to enable us to move about and act in the real world. In practice we can substitute the conceptual world for the real one, but theoretically the two must be distinguished. The conceptual world is only a secondary product of the real world itself, a construction, which the organic beings of this world develop from within themselves.“ (p. 63e, 88-89, my emphases added)

"We must therefore regard it as a pardonable weakness on the part of science if it believes that its ideas are concerned with reality itself." (p. 67e, 97)

“... the ordinary man takes everything that is asserted as undoubtedly natural and true and, at first, not only supposes that the concepts of thought are representative of reality, but regards mental methods and processes [Methoden und Wege des Denkens] as identical with the processes and laws of reality itself - an error subsequently canonized by eminent philosophers. Only in the course of time is it observed that subjective methods are quite distinct from objective happenings.“(p. 99e, 173) 


\section{Vaihinger's scaffolding metaphor}

On pages 68-69e, 99-100, Vaihinger introduces his own scaffolding metaphor: fictions are mere auxiliary means (Hilfsmittel), instruments, scaffolding (Gerüste) to be removed afterwards, when their function is completed.

Semi-fictions are provisional concepts that are removed historically: they are replaced by new concepts that render better services. Real fictions are removed logically: as they contain internal contradictions, they must fall out after being used in calculations to obtain usable results:

"... the discarding of true fictions [echte Fiktionen] in the course of a given mental operation [im Laufe der Denkrechnung] follows necessarily from their contradictory character - for, after all, our aim is to obtain non-contradictory results. Contradictory ideas are thus only there to be finally eliminated; moreover, in spite of these contradictory ideas, correct results are obtained in thought and calculation, and these fictions must somehow be eliminated and their contradictions cancelled.“ (p. 98e, 173)

One of Vaihinger's favorite examples is presented on page 111e, 198: "the theoretical fiction of freedom has been invented" to justify the possibility of punishment under criminal laws. After the laws are formulated, "the idea of freedom drops out". Here is another favorite example:

"Thus, an idea like immortality may be necessary for a time in order to give birth to moral ideas. But once these have been developed, the scaffolding, i.e., the concept in question, can be demolished.“ (p. 130e, 226).

As we see, Vaihinger's enthusiasm about "discarding, demolition" (Wegfallen, Beseitigen) of real fictions is inspired by his enthusiasm for their internal contradictions. However, what remains of such a scaffolding concept after we have recognized that these contradictions are merely avoidable UCT-contradictions? In the corrected model, for unobservable fictions, Vaihinger's scaffolding metaphor should be qualified as a promotion of the elimination of theoretical terms! The results of theoretical calculations using unobservables become usable in practice only when expressed finally in terms of observables.

However, the idea of demolition is not completely harmless: it is orienting us to regard science as a flat, unordered collection of appearing and disappearing constructs. We will see below that this was not Vaihinger's intention.

\section{Fictions are not hypotheses.}

Vaihinger's introduction of fictionality as a new cognitive status for concepts requires reconsideration of the actual status of many of them. Frequently, many concepts that are, in fact, fictional are considered to be hypotheses or even dogmas. Vaihinger protests continually against this practice. This is why the term Hypothese occurs in his text extremely frequently, about 470 times. Of these, about 104 occurrences precede, somewhat informally, Chapter XXI - "The Difference between Fiction and Hypothesis, " where the problem is explained in detail.

Vaihinger mentions many examples where treating of fictions as hypotheses leads 
“... all those antinomies and contradictions ... which run through the history of philosophy from its origins to the present day.“ (p. 105e, 186)

Chapter XXI begins with Vaihinger's own specific definition of the term "hypothesis":

\begin{abstract}
"An hypothesis is directed towards reality, i.e., the ideational construct contained in it claims, or hopes, to coincide with some perception in the future. It submits its reality to the test and demands verification, i.e., it wants to be proved true, real, and an expression of a reality. Every hypothesis without exception endeavours to establish a reality [ein Wirkliches statuieren], and even though we are still uncertain as to the actual occurrence of something hypothetically assumed, we yet entertain the hope that the assumption will eventually prove to be true." (p. $85 \mathrm{e}, 144)$
\end{abstract}

Thus, Vaihinger understands hypotheses in a narrower sense than usually: for him, hypotheses are assumptions about sensations which are pretending to be true, and can be verified by exploring the sensations directly.

For example, Kant's Ding an sich, the idea of independent reality as the cause of our sensations ("located beyond them") is not a hypothesis because it cannot be directly verified and confirmed as "true." It is a fiction, and fictions are fundamentally different:

"To the verification of the hypothesis corresponds the justification of the fiction. If the former must be confirmed by experience, the latter must be justified by the services it renders to the science of experience [Erfahrungswissenschaft].“(p. 88-89e, 150)

“... the real difference between the two is that the fiction is a mere auxiliary construct [blosses Hilfsgebilde], a circuitous approach [blosser Umweg], a scaffolding afterwards to be demolished, while the hypothesis looks forward to being definitely established. The former is artificial, the latter natural. What is untenable as an hypothesis can often render excellent service as a fiction,...“ (p. 88e, 148)

“... The hypothesis tries to discover, the fiction, to invent. ... natural laws are discovered but machines invented. Fictions, as scientific mental instruments [Denkinstrumente] without which a higher development of thought is impossible, are invented.... The atom is not a discovery of natural science but an invention." (p. 88e, 149-150)

"One single fact at variance with it can destroy an hypothesis. This does not hold at all in the case of the fiction: neither its contradiction of experience nor even logical objections [i.e., internal contradictions] can disturb it, or at any rate, they disturb it quite differently from an hypothesis.“ (p. 89e, 152)

Vaihinger's in-consequence: extending the world of sensations?

After the clearly stated (though unusual) concept of hypothesis as an assumption "claiming, or hoping to coincide with some perception," Vaihinger's treatment (on the same page!) of the thesis "Man is descended from the lower Mammals" as a hypothesis comes as a surprise:

"If, therefore, we put forward the hypothesis that Man is descended from the lower Mammals, we are definitely insisting upon the actual existence [wirkliche Vorhandengewesensein] of direct and indirect ancestors of Man, we are expressing the belief that had 
we lived at that time - a fiction impossible from the practical standpoint but logically necessary - they would have presented themselves to perception, and the hope that the remains of these vanished links may still be discovered. We are compelled to frame this hypothesis by the law of causality. For according to this law, to which there has hitherto been no known exception, every phenomenon is to be explained by some other, unless it be an elementary one. And since the human organism shows every indication of not being an elementary phenomenon, it must be regarded as the result of other phenomena. We therefore infer the existence of a still unknown link - the missing link - a necessary causal relation on the analogy of interconnections otherwise known to us. What we infer and hypothetically assume is the existence of an intermediate form from which the men of to-day are directly descended according to unalterable laws of sequence. This is an hypothesis.“ (p. 85-86e, 144, emphases of German original retained)

But Goethe's earlier idea of "an animal archetype" (Urtier), on the contrary, is qualified as a fiction:

"It was recognized, after a time, as a heuristic fiction, but it has now been given up because the correct view has taken its place in the Darwinian theory... ... Goethe's fiction prepared the way heuristically for the Darwinian hypothesis." (p. 86e, 145)

Vaihinger repeated this thesis at the end of Part II (p. 267e, 605).

As we see in the above long passage, Vaihinger extends his notion of the world of sensations "far back in time." This could be inspired by the common-sense intuition based on local practical experiences, and it allows us to imagine ourselves (by analogy) experiencing situations at times and places when and where we will never be able to arrive. For example, we can imagine watching the death of Socrates together with his friends (my example) or searching for food together with the "missing link" (Vaihinger's idea). Only in this way could he arrive at the qualification of Darwin's theory as a hypothesis in Vaihinger's sense, namely, as a concept potentially "coinciding with some perception“.

This in-consequence was noticed by Glasersfeld (1991), who refused (because of it) to recognize Vaihinger as a radical constructivist:

"Hier, wie in vielen anderen Beziehungen, fällt der radikale Konstruktivismus mit Hans Vaihingers "Philosophie des Als Ob" (1911) zusammen; er setzt sich jedoch von Vaihinger dort ab, wo jener der biologischen Entwicklungsgeschichte ontologischen Charakter verleiht.“

"Here, as in many other respects, the radical constructivism coincides with Hans Vaihinger's "Philosophie des Als Ob" (1911); however, it breaks away from Vaihinger at the point where he is granting an ontological character to the biological evolution history.“

For another case of such an in-consequence see page 22 of the German original (left out of ET), where Vaihinger agrees with Steinthal that the heliocentric system (die Drehung der Erde um die Sonne) was derived in the "natural way" by using induction and deduction (auf diesem natürlichen Wege), and hence, it does not represent a fiction invented to go beyond sensations. Here, the world of sensations is extended "far away in 
space, " up to an image of our space-ship landing on a planet in the Andromeda Galaxy (my example).

In a general form, the idea of the "extended world of sensations" is included in Vaihinger's notion of "descriptive and historical sciences":

"Induction shows the direct route by which our goal is to be approached and obstacles overcome, whereas fiction points out the indirect ways, the by-paths. Induction is thus a methodology of the descriptive sciences; fiction, a method of the exact mathematical and the ethico-political sciences, and with hardly any application at all in the domain of the descriptive or historical sciences. In the case of the latter we are not concerned with the theoretical understanding as in the mathematical, but with a determination of causal connections, which is only possible through careful observation and objective description."

"We should not, for example, be able to get very far in the natural sciences [Naturgeschichte, natural history] or world-history [Weltgeschichte] by means of fictions. In the latter [in ET: former] only hypotheses can be used, while for natural history only an artificial classification is appropriate. On the other hand, the fiction is all the more necessary for the other sciences, where it is not possible to make any progress with deduction and induction alone.“ (p. 79e, 126-127)

Thus, here, Naturgeschichte (geology, botany, zoology) and Weltgeschichte are qualified as purely empirical ("descriptive and historical") sciences having as their subject the "empirical" history of the planet Earth and human society on it. It is this seemingly "empirical" history that represents Vaihinger's extended world of sensations in which we can imagine ourselves moving backward through thousands and thousands of years.

However, this notion is not in fact as empirical as it may seem. It includes a mix of highly non-trivial knowledge, theoretical knowledge (such as Darwin's theory) included. How do people know (those who know) that Socrates existed, that he lived in the $5^{\text {th }}$ century BCE (what is this?), and the details of his death? Where does this knowledge come from and what kind of evidence do we have for it?

Of course, the idea of the "extended world of sensations" contradicts Vaihinger's above-mentioned "critical positivism up to limits," which claims that even our nervous systems and brains are fictional constructs, and his declared ambition to completely demystify philosophy. Aller Dogmatismus ist hier verschwunden. Really?

\section{Treating fictions as hypotheses?}

How could one treat a fiction as a hypothesis? Strictly speaking, real fictions (such as Ding an sich or atoms) being internally contradictory constructs (Vaihinger's original concept), or unobservable structures invented for going beyond sensations (in the corrected model), cannot be asserted as hypotheses in Vaihinger's sense, even in principle. "Sensations are caused by an independent reality" and "matter consists of atoms": how could one treat these fictions as hypotheses, when neither of them can "hope to coincide with some perception in the future," as required in Vaihinger's definition of hypotheses?

In fact, however, people use the term "hypothesis" in a broader sense, as any assumption that can be accepted or rejected. In particular, they regard as hypotheses assumptions that pretend to reveal what is "in fact" located beyond sensations. In this way, 
one may regard Kant's fiction of Ding an sich as a hypothesis claiming that sensations are "indeed/really" caused by a "real" independent reality located beyond sensations. But since, obviously, we will never be able to verify directly the "truth" of such an assumption, such hypotheses are fundamentally different from hypotheses about sensations. Contrary to the cherished usual assumption, "hypotheses in the broader sense" can only be justified by the services they render to us.

Despite his specific definition of hypotheses given (as late as) in Chapter XXI, Vaihinger uses the broader sense when mentioning the many cases in which people treat fictions as hypotheses, "transforming fictions into reality," and thus running into the "crudest contradictions". Let us list some of the most striking cases:

a) Smith's egoism-based economic system represents, in fact, an abstractive semifiction, but some consider it to be a hypothesis or even a dogma (see below) by regarding egoism as the sole human motivation in real society (p. 19-20e, 29-30).

b) Freedom/liberty and ethical ideals represent, in fact, practical fictions. However:

"For centuries liberty has been regarded not merely as an hypothesis but as an unassailable dogma. It then fell to the rank of a disputed hypothesis, and to-day it is already often regarded as an indispensable fiction. A bitter struggle was necessary before we attained our present attitude, which for a long while was far from general. On this modern view there is nothing in the real world corresponding to the idea of liberty, though in practice it is an exceedingly necessary fiction.“ (p. 43e, 60, my emphasis added)

"Ideals are not hypotheses. They would be hypotheses if they were attainable or had been realized in any part of the world; but they are fictions." (p. 48e, 67)

c) Infinitesimals:

"If the circle is regarded as a polygon, this is a formal identification at the expense of a qualitative difference, the circle being regarded $a$ s if it were a polygon consisting of an infinite number of sides, infinitely small.

That such fictions lead to contradictions is clear from the inferences drawn by Zeno, which were based upon the fact that the fiction of spatial and temporal atoms (infinitely small divisions of space and time) was taken seriously and transformed into reality. The fiction became an hypothesis and the crudest contradictions followed." (p. 52e, 73, emphases of German original retained)

\section{Dogmas and dogmatism}

The terms Dogma/Dogmen/Dogmatik/dogmatisch/Dogmatismus occur in the text about 113 times; of these, about 23 appear prior to the definition, which appears in Chapter XXVII where Vaihinger defines dogmas as

“... groups of ideas [Vorstellungsgruppen] which are without hesitation [ohne Zweifel

daran] regarded as the expression of reality“ (p. 125e, 220).

Thus, "dogmas" are on a par with the above-mentioned broader sense of the term "hypothesis". A hypothesis is any assumption that can be accepted or rejected, including assumptions pretending to reveal what is, "in fact," located beyond sensations. Dogma is an assumption of the same kind, but it is already accepted and no doubts remain (or none ever existed; ohne Zweifel daran). This is how one can treat a fiction not only as a hypothesis, but even as a dogma (examples below). 
"Dogmatism is a form of logical optimism which approaches the logical functions and their products [i.e., human thinking and its products] with unbounded confidence, regards thought with an admiration and satisfaction so exaggerated that doubts are not raised at any point.“ (p. 162e, 293)

Thus, this is the exact meaning of Dogmatismus in the thesis: "Aller Dogmatismus ist hier verschwunden." (Vaihinger about his book, according to Simon et al. 2013).

Ideational shifts: from dogmas to hypotheses and fictions (and vice versa) Let us begin by listing some of the most striking cases:

"We find the same development [from dogmas to hypotheses and fictions] in Christianity. Its original dogmas became hypotheses for the philosophers of the seventeenth and eighteenth centuries. But what were they to men like Kant or Schleiermacher? Merely fictions! “ (p. 129-130e, 225)

"The Platonic myths (of the transmigration of souls, etc.) were originally fictions, which in the mind of their originator had already been transformed from $\mu \dot{v} \theta o \zeta$ [mýthos] to $\lambda o ́ \gamma o \zeta$ [lógos], i.e., had become hypotheses under the influence of the equilibration [Ausgleichung] of psychic tensions. With his followers, for example the Neoplatonists, they became true dogmas. Later on they resumed the status of hypotheses, and to-day, to students of Plato, they are pure fictions, mythical ideational forms.“ (p. 130e, 225)

"Linnaeus and Adam Smith built up their respective systems as purely artificial ones. Their followers either turned them into hypotheses or interpreted them as hypotheses (for it requires a high degree of mental training [ein hochgebildeter Geist] to recognize an idea as fictive), and then these hypotheses themselves at once became dogmas. Adam Smith's system was later regarded as an hypothesis, and since [Henry Thomas] Buckle's convincing demonstration it has been treated almost universally as an artificial system built up on a fiction. But the idea was regarded earlier so definitely as an hypothesis or dogma that it was believed not only that all actions were egoistic but that it was actually necessary so to act..." (p. 131e, 226-227)

Thus, for different people and at different times, a single idea can possess a different cognitive status: dogma, hypothesis, or fiction.

Even the existence of an independent reality beyond our sensations can be treated not only as a dogma that is true without any doubt, but also as a hypothesis that is probably true, or even as a deliberate fiction, as a useful idea which enables the calculation of events and actions.

In Chapter XXVII - "The Law of Ideational Shifts“ (Das Gesetz der Ideenverschiebung), Vaihinger considers this cognitive phenomenon in detail: how and why ideas pass through stages of being dogmas, hypotheses, and fictions, and/or vice versa. For him, passing from left to right represents a positive "scientific process of regression (Rückbildung)," and from right to left - a negative "nonscientific transformation (Umbildung)“ (p. 127e, 222). 


\section{Logical theory of fictions}

On pages 116-123 of the German original Vaihinger proposes an "Overview of elementary fictional methods" that are used to create fictions (Übersicht der fiktiven Elementarmethoden). This chapter was left out of ET entirely.

Vaihinger's list contains 16 methods, six of which are considered in some detail: decomposition (Zerlegung), composition (Zusammenfassung), symbolic notation (symbolische Bezeichnung), isolation (Isolierung), abstract generalization (abstrakte Verallgemeinerung), and unjustified transference (unberechtigte Übertragung).

Vaihinger concludes that in addition to the logic of deduction and induction, a third chapter must be added to the system of logic - the logical theory of fictions:

“... taking fiction in its broadest sense of fictive activity, we place it on an equal footing with deduction and induction as a third member in the system of logical science." (p.

$79 \mathrm{e}, 124)$

In the following nine chapters (Chapters XIX-XXVII), Vaihinger elaborates on his version of the logical theory of fictions.

\section{The basic problem of the theory of knowledge}

In Chapter XXXV, Vaihinger formulates this problem as follows:

"How does it happen that although in thinking we make use of [rechnen, i.e., calculate with] a falsified reality, the practical result still proves to be right? “" (p. 159e, 289)

This is a natural question to ask for people who think (as Vaihinger) that only sensations are directly accessible to us, that "we do not know objective reality [beyond sensations] absolutely but only infer it", and that it is impossible to verify these inferences as true in any absolute sense. Why, then, do the practical consequences of our inferences still "prove to be right"?

An optimistic answer follows immediately:

"The course of nature is unchangeable and proceeds according to hard and unalterable laws. Nature has an iron Will; but thought is an adaptable, pliant, and adjustable organic function.“( p. 159e, 290)

Thus, Vaihinger's cognitive optimism is based on his belief in the universal adaptability of thought.

In trying to calculate the most complicated cases of "unalterable sequence and coexistence" of sensations, people are forced to invent fictions. According to Vaihinger, the invention process starts with the fiction of Ding an sich (the idea of independent reality located beyond sensations), followed by categories (analogical fictions): thing and its attributes, the whole and its parts, cause and its effects, the general and its particulars (p. 170e, 308).

People have selected these categories from among many possibilities:

“.... an indefinitely large number of categories are conceivable. We might even say that the mind once possessed a far wider range of categories [viel reichere Kategorientafel] than to-day, that the present list is only the result of natural selection and adaptation. The traces of earlier categories are evident in all languages and those of to-day show 
the nature of their origin very clearly. They are manifestly analogies. A priori, however, a very large number of analogies are possible and have been employed in the course of history. Categories are nothing but analogies according to which objective phenomenal events have been interpreted [erfasst].

They are, therefore, in no sense innate possessions of the psyche, but analogies which have been selected and applied in the course of time, and according to which events have been interpreted." (p 172e, 313)

Thus, Vaihinger insists that categories "have been selected", and, hence, are not synthetic a priori concepts ("innate possessions of the psyche"). Nevertheless, he qualifies them as "indispensable" for thinking and even as "immortal":

“... these epistemological fictions, i.e., the categories, in particular, are absolutely indispensable [ganz unentbehrlich] for thought, for otherwise thinking could not be discursive at all." (p. 107e, 191)

"Some of these fictions are immortal, those that make discursive thinking itself possible - the categories and general ideas [Allgemeinbegriffe]. But this is only in their capacity as fictions, with the consciousness that they are fictions.“ (p. 132e, 228)

Fictions cannot create "real knowledge."

At the very end of Part I, in Chapters XXXVII-IX, Vaihinger elaborates on this seemingly paradoxical thesis which is mentioned several times throughout the book: the purpose of fictions is a practical one - enabling and facilitating the calculation of events and actions, but "they do not create real knowledge" (eigentliches Wissen) ( $p$. $88 \mathrm{e}, 148)$, to them, "there is no corresponding objective reality (Wirklichkeit)" (p. 49e, 68).

Of course, the meaning of these theses depends on the meaning of the term "real knowledge“" The best explicit definition was left out of ET:

“... eigentliche Erkenntnis ist bekanntlich nur Einsicht in die notwendigen Aufeinanderfolgen und Gleichzeitigkeiten des Geschehens. Alles andere ist scheinbares Erkennen. Die Umsetzung des Empfindungsmaterials in die begriffliche Form erzeugt gar keine eigentliche Erkenntnis, sondern nur ein Lustgefühl, ...“ (p. 307-308)

“... it is well known that real cognition is only an insight in the unalterable successions and co-existences of events. All the rest is merely an apparent cognition. Conversion of sensational stuff into conceptual form does not provide any real cognition at all, it provides only a feeling of pleasure, ..."

Thus, in fact, the above seemingly paradoxical theses are simply re-formulations of Vaihinger's distinction between hypotheses and fictions. For Vaihinger, real knowledge is directly about sensations. "All the rest is merely an apparent cognition", from the simplest cases - "conversion of sensational stuff into conceptual form" - categories and general concepts, to real/unobservable fictions.

As an example of "conversion of sensational stuff into conceptual form" let us consider one of the categories - "thing and its attributes" (Ding-und-Eigenschaften), elaborated in Chapter XXXVII: 
"Thought creates an object [ein Ding] to which it attaches its own sensations as attributes and then, by means of this fiction, disengages itself from the mass of sensations that rush in from all sides.

...

The creation of this fictional thing has, however, an enormous practical value, for it serves as the nail to which the sensations are attached as attributes. Without its aid it would not have been possible for thought to create any order at all out of the confusion of sensation [Wirrwarr der Empfindungen].“ (p. 169e, 305-306, emphases of German original retained)

Thus, the nail itself (thing) is a fiction, an invention, not to be found in sensations. But, for human thinking, it serves as a means "to create order out of the Wirrwarr of sensations."

According to Vaihinger, real fictions do not create "real knowledge" because of their internal contradictions. But what about the corrected model, in which the seemingly contradictory real fictions are considered as unobservable fictions that are invented as structures for going beyond sensations? Of course, this method does not create knowledge that is as "real" as direct knowledge of "the unalterable successions and co-existences of events." It can be justified, but not verified.

\section{The wish to understand the world is a very stupid wish.}

This represents another seemingly paradoxical statement. According to Vaihinger, "understanding" (Begreifen) means establishing analogies:

"All cognition is the apperception of one thing through another. In understanding, we are always dealing with an analogy and we cannot imagine how otherwise existence can be understood. ... The only ideational constructs by means of which existing things can be apperceived are either the corresponding general conceptions or other concrete objects. ... it is utterly impossible to attain knowledge of the world, not because our thought is too narrowly circumscribed - this is a dogmatic and erroneous interpretation - but because knowledge is always in the form of categories and these, in the last analysis, are only analogical apperceptions." (p. 29-30e, 42)

"Understanding is the well-known feeling of pleasure [Lustgefühl] due to the empirical transformation of sensations into categories.... Science in the end always leads us back to unalterable sequences and co-existences; and here there is nothing "understandable", ... (p. 171e, 310)

“... all understanding consists in an actual or imaginary reduction to the known [Bekanntes]. But to what is this "known" itself to be reduced, especially if in the end it turns out to be something ”unknown” [Unbekanntes]? “(p. 171e, 310)

Therefore, "the wish to understand the world" as the whole and right now

“... is not only unrealizable [unerfüllbar], but also it is a very stupid wish [ein törichter Wunsch].“(p. 171e, 310)

"Our world itself is not capable of being understood but merely of being known. [Somit ist die Welt selbst nicht begreiflich, nur wissbar.]" (p. 171e, 311) 
"The categories, particularly cause (and purpose) can be usefully applied only within sensory material which is given. When applied to the whole, they lose all theoretical as well as practical value and only engender illusory problems as, for example, the problem concerning the origin and purpose of cosmic events.“ (p. 171-172e, 311)

"Die grossen Weltfragen entstehen, wie wir schon sagten, durch unberechtigte Übertragung von Kategorien: also wenn wir die ethischen Kategorien auf das Sein anwenden, entstehen alle jene Fragen nach dem Zweck des Lebens u. s. w., welche ebenso nichtssagend als quälend sind.... Nur der Mensch ist ethisch, logisch - nur er will eine ethische, eine logische Weltordnung schaffen.“ (p. 160, left out of ET)

"The great world problems emerge, as we already said, by unjustified transference of categories: thus, when we apply ethical categories to reality, all these questions emerge about the purpose of life, etc., which are as vacuous as tantalizing. ... Only humans are ethical, logical - only they wish to create an ethical, logical world order." (my emphasis edded)

\section{About terminology: zweckmässig}

Expediency (utility, purpose) is an essential feature of Vaihinger's concept of fiction. Scientific fictions are invented with a definite purpose in mind:

"A further essential character of fictions, i.e., of scientific fictions, is that they are means to a definite end [Mittel zu bestimmten Zwecken], in other words that they are expedient. Where there is no expediency [Zweckmässigkeit] the fiction is unscientific.... For us the essential element in a fiction is not the fact of its being a conscious deviation from reality, a mere piece of imagination — but we stress the useful nature of this deviation.“ (p. 99e, 174)

In the German original, terms having the root zwecktätig occur about 22 times, and these terms Ogden translates consistently as "purposive" or "purposeful."

Terms having the root zweckmässig occur about 111 times, but these terms Ogden translates in an extremely irregular way. For example, in the first 11 occurrences of this root, Ogden translates 3 times: Zweckmässigkeit - as "utility"; 2 times: zweckmässig - as "useful", zweckmässig - as "fittingly"; 1 time: Zweckmässigkeit - as "appropriateness"; zweckmässige Aneignung - as "appropriation"; and 2 times the terms Zweckmässigkeit/zweckmässig are omitted at all.

However, consistently and many times, the translation of "expedient" as an adjective in the German original, means zweckmässig, and "expedient" as a noun means Hilfsmittel or Denkmittel (expedient of thought, mental expedient).

So, when translating zweckmässig in the fragments left out of ET, I use the term "expedient."

\section{Evolution of science}

In Chapter XX, comparing scientific fictions with aesthetic fictions in poetry and art, Vaihinger presents his interpretation of the evolution of science:

“... alte Fiktionen sterben allmählich aus, neue treten an ihre Stelle: es ist ein beständiges

Wogen, ein Kampf. ... Nun geht allerdings die Wissenschaft, im Unterschied von der 
Poesie, darauf aus, letztlich einheitlich zu werden: dies entsteht aber nur dadurch, dass unzweckmässige Vorstellungsgebilde ausgerottet werden und die zweckmässigsten an ihre Stelle treten.“ (p. 135, left out of ET)

"... gradually, old fictions are dying out, new ones come in place: there is continuous heave and struggle. ... However, science, contrary to poetry, tends to become unified in the end: but this is attained only by wiping out the inexpedient ideational constructs, and replacing them by the most expedient ones."

Throughout the book, Vaihinger mentions several cases of theory-change: Goethe's idea of Urpflanze und Urtier versus Darwin's theory (p. 86e, 145), Ptolemy (p. 40e, 55) versus Copernicus (p. 437, left out of ET), Newton's theory of light versus the theory of Huygens-Fresnel (p. 435, left out of ET).

Dying out and replacing - does this mean that the architecture of cognition proposed by Vaihinger is only "one-floor," a flat unordered collection of fictions, appearing and disappearing in the course of history? Not at all, because "science, contrary to poetry, tends to become unified in the end." Vaihinger finds a hierarchy or system among the fictions - some fictions are built on top of other:

“... the whole mechanism of thought is an articulated system [ein gegliedertes System] of expedients which mutually support one another, so that fictions serving primarily to perfect the instrument itself become in due course an accessory of this very instrument.“ (p. 70e, 101, emphasis of German original retained)

And finally, let us remember that Vaihinger qualifies some of the fictions as indispensable for discursive thinking to be possible at all (see above).

\section{Vaihinger's notion of truth}

As noted above, Vaihinger rejected the traditional correspondence approach to truth:

“... From the standpoint of modern epistemology [in 1876!] we can therefore no longer

talk about "truth" at all, in the usual sense of the term." (p. 3-4e, 4-5)

According to Vaihinger, "truth in the usual sense" applies only to our knowledge about the world of sensations in the form of certain knowledge, hypotheses and semi-fictions.

Inductively established general judgments about the world of sensations can be safely considered as true:

"These philosophers [Greek sophists and skeptics] undoubtedly went too far in questioning the material validity of general judgments; for the establishment of an unchangeable sequence and co-existence (or at any rate one that has never changed within our field of observation) is certain knowledge [sicheres Wissen].“ (p. 68e, 97, my emphasis added)

However, speaking strictly, the idea of certain knowledge contradicts Vaihinger's abovementioned "critical positivism up to limits," which claims that even our nervous systems and brains are fictional constructs.

Hypotheses (in Vaihinger's sense) are concepts not yet confirmed as certain knowledge, but they pretend to be so ("claiming, or hoping, to coincide with some perception 
in the future“). Disproved hypotheses are either discarded or, being false but still useful, retained as semi-fictions.

And finally, some of the semi-fictions are deliberately, from the very beginning, created as false but useful provisional concepts (such as Smith's egoism-based economic system and other abstractive fictions), to be replaced in the future by better-serving concepts.

For real fictions, Vaihinger's definition of truth is repeated several times throughout the book, but the best formulation was left out of ET:

"Das, was wir wahr nennen, ist nur das Produkt einer logischen Selektion, indem allmählich alle unzweckmässigen Gebilde eliminiert werden und nur die zweckmässigen bleiben; auch im Psychischen gab es, wie wir oben sagten, ursprünglich wohl viel mehr Verbindungsformen, bis sich schliesslich durch Selektion diejenigen erhielten, welche den Dienst am besten erfüllten.“ (p. 101, left out of ET).

"What we are calling true, is mere the product of a logical selection, when all inexpedient concepts are gradually eliminated, and only the expedient ones remain: also in the psychical realm, as we said it above, initially, there were many more connection forms, until ultimately only those were retained by selection, which best performed their service."

The opposite term to wahr (true) is falsch (false), but as the opposite of Wahrheit (truth) Vaihinger uses the term Irrtum. Ogden translates Irrtum as "error."

Truth and error both fall under a common umbrella term:

"Irrtum und Wahrheit fallen unter den gemeinsamen Oberbegriff des Mittels zur Berechnung der Aussenwelt; das unzweckmässige Mittel ist der Irrtum, das zweckmässige heisst man Wahrheit. Das mit Notwendigkeit Gedachte ist noch nicht wirklich: denn jene Notwendigkeit ist nur ein Gebot der Zweckmässigkeit.“ (p. 193, left out of ET)

"Error and truth fall under the common umbrella term: means for calculation of the external world; the inexpedient means is the error, the expedient one is called truth. What is thought with necessity is not yet real: because this necessity is mere a requirement of expediency."

Some real fictions (Ding an sich, categories, etc.) are declared by Vaihinger as "immortal,“ as indispensable for discursive thinking to be possible at all (see above), but even this does not imply with certainty that the reality located beyond sensations is exactly the same as that claimed by real fictions. "We do not know the objective reality absolutely but only infer it.“

"True criticism or logical positivism [Vaihinger's own philosophy] proceeds to examine the thought instrument dispassionately and objectively. With logical pessimism it frees itself from childish beliefs in the power and unlimited validity of thought, and with optimism it holds firmly to the fact of the ultimate practical coincidence of thought and existence. The valuable outcome of pessimism is the habit of seeing in these conceptual constructs primarily nothing more than subjective products." (p. 163e, 295-296, emphases of German original retained) 
Thus, Vaihinger declares his position ("critical positivism") as including both "logical pessimism" (a mild form of skepticism: "conceptual constructs primarily [are] nothing more than subjective products") and "logical optimism" (a mild form of dogmatism: "ultimate practical coincidence of thought and existence").

However, it seems Vaihinger would accept some of the concepts going beyond sensations as "truths about reality" if these concepts were proved to provide the only possible way how "the empirical appearance of material phenomena can be explained" (see above the curious quote about atoms from p. 94e, 166).

\section{Idealistic Positivism}

I will not try to qualify Vaihinger's philosophy as one or several of the "isms" proposed before and after 1876.

Throughout the book, Vaihinger himself qualifies his philosophy (10 times in Parts I and II) as "critical positivism, " but in the title of the book (introduced in 1911) appears the term "idealistic positivism." In Vorbemerkungen zur Einführung (p. XX, left out of ET) another term, "positivistischer Idealismus" is admitted as a synonym as well.

The starting point (recognition of the world of sensations as the only accessible reality) represents the positivist side, and the recognition of the ubiquitous success of fictions represents the idealist side of Vaihinger's philosophy.

\section{Why, "Philosophie des Als Ob"?}

Vaihinger's own statement from his reminiscences (1921):

"[In 1911] I called this work, The Philosophy of 'As if' because it seemed to me to express more convincingly than any other possible title what I wanted to say, namely that "As if", i.e., appearance, the consciously-false, plays an enormous part in science, in world-philosophies and in life." (p. XLIe of ET).

According to Vaihinger, people invent fictions in trying to capture the world around them. They use more or less suitable fictions to guide their actions in this world "as if" it (the world) were as claimed by the fictions.

In the General Introduction and Parts I and II of the book (written in 1876-1878), the conjunction als $o b$ (in the above sense) occurs about 138 times, but for the first time on page 17e, 26. Most of these occurrences (102) refer to cognitive fictions (52betrachten als ob, 22 - rechnen als ob, 28 - behandeln als ob, denken als ob, scheinen als $o b$, sprechen als $o b$, etc.), 16 refer to ethical fictions (11 - to the fiction of man as a free agent), 8 - to legal fictions, and 12 - to religious fictions. Of the 102 cognitive references, 24 are to mathematical fictions, 6 - to the fiction of atom.

Sentences containing "as if" are judgements:

"The basic form of this fictive chain of thought is the following: A is to be regarded as if (as though) it were B or: A is to be regarded as if it were B (although it is not B)." (p. 260-261e, 592, my emphasis added) 
Examples:

"“"God" is not the "father" of men but he is to be treated and regarded as if he were." (p. $28 \mathrm{e}, 41)$

"A careful psychologist and jurist does not say that man is a free agent [der Mensch ist frei], but that man must, at any rate legally, and from the moral standpoint, be regarded and treated as if he were free." (p. 95e, 167)

"The circle is to be regarded as [if it were] a polygon of infinitely numerous and infinitely small sides." (p. 263e, 601)

"... matter is so to be regarded, treated and reckoned with as if it consisted of atoms." (p. 268e, 605)

The conjunction "as if" is used, because:

"The judgment is made with the consciousness of its non-validity, but at the same time it is tacitly presupposed that this operation is permissible, useful and appropriate for the subject, for the subjective manner of approach.“ (p. 261e, 593)

Thus, "as if" is used to specify an application of a fiction: A is to be (must be, can be) regarded (treated, reckoned with, etc.) as if it were B (although A is not B).

To specify application of fictions, another 29 times Vaihinger uses the terms "substituieren / Substitution / an Stelle setzen": B is substituted for A (B ist an Stelle von A gesetzt). The most striking example (for the exact quote, see above) is "In practice, we all substitute our world of ideas for the actual world." In general, "all fictions may be regarded as substitutions":

"This substitutional method is of use as a convenient aid to thought in other respects too. Indeed, in a wide sense, all fictions may be regarded as substitutions, in that an unreal element is provisionally put in the place of reality." (p. 214e, 415-416, my emphasis added)

\section{From the modern viewpoint, 140+ years later}

What should be said about Vaihinger's analysis of human cognition 140+ years after it was proposed, after the emergence of relativity theory, quantum theory, the Standard Model of particle physics, Big Bang cosmology, molecular biology, plate tectonics, computers, artificial intelligence, etc.?

\section{Thinking as computation}

First of all, I would praise Vaihinger for trying to establish, in 1876, Berechnen (calculation, computation) as one of the fundamental concepts of philosophy. The term (as a verb and a noun) occurs 112 times in the General Introduction and Parts I and II. Additionally, Vaihinger applies 15 times the term Denkrechnung (Denken - thinking, Rechnung - calculation), 6 times - the term Denkmaschine, and 6 times - the term denkmechanisch/Denkmechanismus. 
Vaihinger refers to Hobbes (p. 154e, 281) as the author of the idea of aligning thinking with calculation ("reckoning"). This idea occurred to Hobbes more than 200 years before Vaihinger (published in 1655; for details, see Duncan, 2019). But in Vaihinger's version, the idea is already free of rationalistic illusions: only by introduction of the construct of independent reality as the cause of our world of sensations (Kant's fiction of Ding an sich) does this world become berechenbar (calculable). This first step is followed by many other similar steps: people invent, try out and select new knowledge constructs (fictions) that allow them to calculate their actions with ever increasing efficiency. Thus, once again, in 1876 :

"The comparison of thought with calculation is far more correct and legitimate than was formerly supposed.“ (p. 153e, 271-272)

\section{The Darwinian argument}

Let us consider once more Vaihinger's line of argument in favor of his "computational architecture" of human cognition.

a) Human thinking developed at a certain stage of animal evolution; hence,

b) it is an organic function of the human body "in the service of life";

c) it is a part of the physical universe ("cosmic process");

d) it takes place in the human brain, hence, it works according to the "mechanical and psycho-chemical" laws of this universe.

Stephen W. Hawking (2002) would have been agreed:

“... we are not angels, who view the universe from the outside. Instead, we and our models are both part of the universe we are describing."

So would one of the founders of computer science, John McCarthy (1996):

"It turns out that many philosophical problems take new forms when thought about in terms of how to design a robot."

I would like to call Vaihinger's argument "Darwinian“. Darwin's book was published in 1859. However, according to Vaihinger's reminiscences (1921), he adopted the idea of human evolution from animals before knowing about Darwin, while reading in 1868 (at the age of 16) Herder's book, "Ideen zur Philosophie der Geschichte der Menschheit," published in 1784-1791:

"In later years there has been much discussion as to whether Herder can be called a forerunner of Darwin. At any rate in my case [ich ... hatte Herder so gelesen, dass] Darwin's theory of descent added nothing new to what I had learnt from Herder." (p. XXIVe).

"Im jugendlichen Übereifer" Vaihinger expressed the point as a striking aphorism that became popular at the time: "Die Menschen sind eine am Größenwahn erkrankte Affenspezies."

"In my excess of youthful zeal I produced a definition which at the time soon became a catchword, and also brought me much hostile criticism: 'Mankind is a species of monkey suffering from megalomania.'“ (p. XXXIIe) 
Starting from the above Darwinian viewpoint (a, b, c, d) Vaihinger's subsequent chain of conclusions seems almost inescapable:

e) Due to the specific substrate of human thinking, the exact copying of reality is impossible; hence,

f) to attain its purpose ("rendering service to life"), thinking has to create artificial means; first of all,

g) "technical rules of thought" - developed for handling the most frequent and regular situations (logic of deduction and induction); however,

h) to handle more difficult situations, people are forced to "give up logical purity“ and invent artifices (fictions).

Thus, in attempting to put thinking into a "mechanical and psycho-chemical device" (human brain), one arrives inevitably at the idea that products of thinking are artificial constructs, human inventions existing in the physical universe apart from the things to which they seem to relate.

In 1930, three years before Vaihinger's death and at the 300th anniversary of Kepler's death, Einstein proposed a striking formulation of this conclusion (Frankfurter Zeitung, 9 November 1930). For an excellent English translation by Sonja Bargmann, see Einstein (1954):

"It seems that the human mind has first to construct forms independently, before we can find them in things. Kepler's marvelous achievement is a particularly fine example of the truth that knowledge cannot spring from experience alone, but only from the comparison of the inventions of the intellect with observed fact."

So, what? Does Vaihinger's Philosophie des $\mathrm{Als} \mathrm{Ob}$ represent a philosophy of modeling?

Fine's proposal: "Vaihinger was surely the earliest and most enthusiastic proponent of this conception, the preeminent twentieth-century philosopher of modeling." (see above).

However, the term "models" (Modellen) appears in Vaihinger's book only once, meaning a "schematic fiction":

"To a certain extent the laws of nature are here studied by means of simpler models

[Modellen] containing, it is true, the essentials of reality but in a much simpler and purer form. The schematic drawings employed in many sciences give us an idea of this method which here finds extensive application.“ (p. 25e, 36-37)

The other 5 occurrences of this term in ET do not count:

On p. 6e, 9 the term "re-modelled" appears as Ogden's translation of umgewandelt (converted).

On p. 294e, 653, "a kind of model" represents a translation of "zum Muster."

On p. 310e, 704, "on the model... of" represents a translation of "nach dem Bilde... von."

On p. 347e, 777, "intellect has modelled his conduct" reproduces Nietzsche's "modeling" quote: "er [Intellekt] hat sein Wesen darnach gemodelt."

On p. 356e, 785, "model-example of a perfect fiction" represents a modernized translation of "das Muster einer vollständigen Fiktion" (Nietzsche, again).

But could Vaihinger's concept of fictional activity be considered as modeling, nevertheless? To compare, we must first adopt a completely demystified concept of modeling. 
Vaihinger's "fictionalism" was intended as a completely demystified philosophy. So, if we, in our concept of modeling, will retain elements of mysticism, then, inevitably, the match with Vaihinger will be incomplete.

\section{Modeling demystified}

Thus, for comparison purposes, let us choose some completely demystified definition of modeling. For example, let us consider the following model-based model of cognition (MBMC). I began promoting MBMC in my papers, Podnieks (2009) and (2014), but the principal ideas are not mine; they can be traced to many brilliant thinkers of the past, among them - philosophers almost neglected by the mainstream: Herbert Stachowiak (1973), Georg Klaus (1966), Marvin Minsky (1965), Leo Apostel (1960), Kenneth Craik (1943), and ... Hans Vaihinger (1876)! For a more detailed exposition of this history, see Podnieks (2018). (For the reference to Craik, I am indebted to Philip Johnson-Laird.)

These ideas can also be found scattered in the work of the actual community of modeling philosophers (see, for example, Knuuttila 2009 and other papers of the volume).

MBMC is based on three ideas:

1. Models are replacements. The diverse functions of models can be best structured as follows: in fact, models perform only a single function: they replace their target systems, but for different purposes. A model is anything that is (or could be) used, for some purpose in place of something else. (This definition follows the elegant formulation proposed by Rothenberg, 1989). Models here are concrete systems that serve or can serve as replacements for concrete target systems (for some concrete purposes).

2. Cognition is the production of models. Models are the ultimate results of cognition, and its ultimate goal. Humans and robots need models (in the above sense) to manage what is happening in the world around them. Models are ubiquitous in cognition. Even perception, reflexes, and animal instincts can be best analyzed as modeling. Cognition is modeling.

More precisely:

3. Cognition is the production of models and the production of means of modelbuilding. Since we need models, we also need means of model-building. Theories ("theoretical laws") are less "noble" than they are usually thought to be. The principal function of theories is to support model-building. Production of the means of model-building represents the key aspect of cognition. These means can be subdivided into: model templates, theories, methods, hypotheses, heuristics, research programs, doctrines, paradigms, frameworks, ontologies, meta-models, meta-meta-models, mathematical structures, logic systems, languages, etc.

Could Vaihinger's Philosophie des Als $\mathrm{Ob}$ be considered a philosophy of modeling according to the above definition?

Fictions are replacements; they are substituted for reality.

Vaihinger included Surrogate and Substitutionen in his list of possible synonyms for the term Fiktion (see above). And, as noted above, he used 29 times the terms substituieren / Substitution / an Stelle setzen as synonyms for his favorite term "as if." In general, 
“... in a wide sense, all fictions may be regarded as substitutions, in that an unreal element is provisionally put in the place of reality." (p. 214e, 416)

Thus, fictions, like models in MBMC, serve as replacements for their "as-if-targets."

"... the purpose of thought must be sought not in the reflection of a so-called objective world [which "we do not know absolutely but only infer it"] but in rendering possible the calculation of events and of operations upon them." (p. 5e, 7)

Serious fictions are created with serious purposes in mind. In the German original, the terms having the roots zweckmässig/zwecktätig occur about 133 times.

Cognition is (largely) the production of fictions.

According to Vaihinger, only knowledge related directly to sensations, can be nonfictional, and it is represented as certain knowledge (sicheres Wissen) and hypotheses (knowledge pretending to become certain after verification). In complicated situations, people are forced to invent preliminary artificial simplified concepts: semifictions/observable fictions.

The most powerful (and most problematic) facet of our knowledge is going beyond sensations, "into the void", "to a non-existent and imaginary realm". To go beyond sensations, people invent real/unobservable fictions, starting with the fiction of independent reality (Ding an sich) as the "cause" of sensations. These fictions are invented "on our side" of sensations, and when we place them beyond sensations, we are reasoning by analogy. In this way, according to Vaihinger, we commit "unjustified transference" and, thus, fall into contradictions (the distinguishing feature of real fictions). However, as we already know, these contradictions are in fact mere UCT-contradictions that can be avoided (see above).

Thus, for Vaihinger, cognition is (largely) the production of fictions.

\section{Fictions versus means of fiction-building}

In his pioneering work, Vaihinger did not yet introduce the distinction between concrete fictions and means of fiction-building in the sense of MBMC.

Only a few of the fictions mentioned in the book, can be qualified as models in the sense of MBMC, as replacements of concrete target systems: Ptolemy's system (p. 40e, 55), the botanical system of Linnaeus (p. 19e, 29) and other systems of classification.

All Vaihinger's other fictions represent, in fact, means of fiction-building, and he proposed a compendium of these means - his logical theory of fictions.

Fundamental fictions such as Ding an sich (independent reality) and categories (things-attributes, whole-parts, cause-effect, general-particulars) represent the most generally successful and widely used cognitive constructs. Thus, these fictions must be qualified as fundamental means of fiction-building.

In Vaihinger's time, the term "theory" was already used in its modern sense. So, he mentions Erkenntnistheorie, die logische Theorie (logic), Galilei-Newtonsche Theorie, Dalton'sche Theorie, Newton'sche Lichttheorie, Huyghens-Fresnel'sche Lichttheorie, Theorie des Elektromagnetismus, Infinitesimaltheorie, etc., and he refers several times Lothar Meyer's 1876 book, "Moderne Theorien der Chemie."

Another interesting feature relates to the term Vorstellungsweise used about 51 times in Parts I and II. Ogden translates this term in various ways: conceptual approach, con- 
ceptual standpoint, system of ideas, method, conceptions, view, mental accessories (Hilfsvorstellungsweise), way of thinking, modes of conception, conceptions, conceptual method, etc. Of course, all these versions relate to the means of fiction-building.

So is the fiction of freedom: according to Vaihinger, it has been invented, in particular, to justify the possibility of punishment under criminal laws. So are immortality and other religious notions: they are necessary "in order to give birth to moral ideas."

Vaihinger proposed fictional activity as the third principal method of scientific thinking: Induktion, Deduktion und fiktive Tätigkeit.

\section{Problematic points}

Let us review the problematic points in Vaihinger's argument elaborated above:

a) Reliance on the (in fact, theory-laden) notion of "natural" systems of classification to qualify other systems as "artificial," "deviating from reality," and even "false." More correctly, precisely defined systems of classification cannot be qualified as "false": they represent a kind of tautology; "they classify as they classify."

b) Reliance on the notion of an "extended world of sensations." Vaihinger applies it as an "empirical" notion allowing us to imagine acting far back in time or far away in space, when and where we never will be able to act. But, in fact, this notion is extremely theory-laden. Treating it as "empirical" contradicts Vaihinger's ambition of the total demystification of philosophy.

c) Enthusiasm about contradictions that are ubiquitous in science and mathematics. In fact, these contradictions are mere UCT-contradictions that can be avoided by more careful transference of knowledge to new situations. To correct this fault, I would propose replacing Vaihinger's original semi-fiction/real fiction distinction by the observable/unobservable fiction distinction.

\section{Conclusion}

In his Philosophie des Als $\mathrm{Ob}$, Vaihinger promotes two of the three main ideas of MBMC:

a) Fictions are replacements.

b) Cognition is (largely) the production of fictions.

The third idea - the distinction between concrete fictions and means of fictionbuilding - does not appear in Vaihinger's book. Almost all the fictions considered in the book, are means of fiction-building.

Thus, we can conclude that in his Philosophie des Als $\mathrm{Ob}$ Vaihinger promotes an almost full-fledged philosophy of modeling. And thus, Hans Vaihinger should be qualified, indeed, as a philosopher of modeling in the modern sense - a brilliant achievement for the 1870s!

And, in the demystification of such principal aspects of cognition as truth, understanding and causality, is he not still ahead of many of us? According to Vaihinger, what we set beyond the world of sensations is our invention (fiction), the correspondence of which with reality cannot (and need not) be verified in the mystical, absolute sense many people expect. 


\section{Acknowledgements}

Of the many internet resources supporting German-English translation, dict.cc by Paul Hemetsberger seems to be the best.

\section{References}

Duncan, S. (2019). Thomas Hobbes, Stanford Encyclopedia of Philosophy (Spring 2019 Edition), Zalta, E. N. (ed.). Available online.

Einstein, A. (1919). Letter to Hans Vaihinger, 3 May 1919, The Collected Papers of Albert Einstein, vol. 9, Princeton University Press, 29-30

Einstein, A. (1954). Ideas and Opinions, Crown Publishers, New York, 262-266

Fine, A. (1993). Fictionalism, Midwest Studies in Philosophy, 18(1), 1-18

Glasersfeld, E., von (1991). Fiktion und Realität aus der Perspektive des radikalen Konstruktivismus. in: Rötzer, F., Weibel, P. (eds): Strategien des Scheins, Klaus Boer, Munich, 161-175

Hawking, S. W. (2002). Gödel and the end of Physics, Public lecture. Available online.

Hentschel, K. (2014). Zur Rezeption von Vaihingers Philosophie des Als Ob in der Physik, in: Neuber, M. (ed.) Fiktion und Fiktionalismus. Beiträge zu Hans Vaihingers 'Philosophie des Als-Ob', Königshausen \& Neumann, Würzburg, 161-186

Knuuttila, T. (2009). Representation, Idealization, and Fiction in Economics: From the Assumptions Issue to the Epistemology of Modelling, in: Suárez, M. (ed.), Fictions in Science. Philosophical Essays on Modeling and Idealization. Routledge, 205-231

Koridze, G. (2014). Vaihinger, James un die alten Athener, in: Neuber, M. (ed.) Fiktion und Fiktionalismus. Beiträge zu Hans Vaihingers 'Philosophie des Als-Ob', Königshausen \& Neumann, Würzburg, 247-263

McCarthy, J. (1996). What has AI in Common with Philosophy. Available online.

Mühlpfordt, G., Schenk, G. (2001). Der Spirituskreis [1890 bis 1958]. Eine hallesche Gelehrtengesellschaft in neuhumanistischer Tradition, Hallescher Verlag, Halle/Saale, Band $1,1-536$

Podnieks, K. (2009). Towards Model-Based Model of Cognition, The Reasoner, 3(6), 5-6

Podnieks, K. (2014). The Dappled World Perspective Refined, The Reasoner, 8(1), 3-4

Podnieks, K. (2018). Philosophy of Modeling: Neglected Pages of History, Baltic J. Modern Computing, 6(3), 279-303

Rothenberg, J. (1989). The Nature of Modeling, in: Artificial Intelligence, Simulation, and Modeling, Wiley \& Sons, 75-92

Sass, H.-M. (1979). Einstein über "wahre Kultur" und die Stellung der Geometrie im Wissenschaftssystem: Ein Brief Albert Einsteins an Hans Vaihinger vom Jahr 1919, Journal for General Philosophy of Science, 10(2), 316-319

Simon, G. et al. (2013). Chronologie Vaihinger, Hans, Universität Tübingen. Available online.

Simon, G. (2014). Leben und Wirken Hans Vaihingers, in: Neuber M. (ed.), Fiktion und Fiktionalismus. Beiträge zu Hans Vaihingers, Philosophie des Als $\mathrm{Ob}^{`}$, Königshausen \& Neumann, Würzburg, 21-41

Steffe, L. P. (2015). Can a Radical Constructivist Be Religious? - Yes! Constructivist Foundations, 11(1), 31-134

Suárez, M. (2009). Scientific fictions as rules of inference, in: Suárez, M. (ed.), Fictions in Science. Philosophical Essays on Modeling and Idealization, Routledge, 158-178

Vaihinger, H. (1922). Die Philosophie des Als Ob. System der theoretischen, praktischen und religiösen Fiktionen der Menschheit auf Grund eines idealistischen Positivismus, 7. und 8. Auflage, Felix Meiner, Leipzig, 1-804 
Vaihinger, H. (1921). Wie die Philosophie des Als Ob entstand. in: Schmidt, R. (Hrsg.) Die Deutsche Philosophie der Gegenwart in Selbstdarstellungen, Felix Meiner, Leipzig, Band 2, 175-203

Vaihinger, H. (1924): The Philosophy of "As if". A System of the Theoretical, Practical and Religious Fictions of Mankind. Translated by C. K. Ogden, Routledge, 2009 (reprint)

Received February 24, 2021 , accepted March 20, 2021 